\title{
EL APRENDIZAJE DE LAS CIENCIAS SOCIALES:
}

Valoración del territorio por los jóvenes de grado noveno de la IED Ofelia Uribe de Acosta.

\author{
Juan Pablo Avella Riaño
}

Universidad de Ciencias Aplicadas y Ambientales U.D.C.A.

Facultad de Ciencias de la Educación

Programa de Maestría en Educación Ambiental

Bogotá. D.C

2020 


\title{
EL APRENDIZAJE DE LAS CIENCIAS SOCIALES:
}

Valoración del territorio por los jóvenes de grado noveno de la IED Ofelia Uribe de Acosta.

\author{
Juan Pablo Avella Riaño
}

Trabajo de grado para optar al título de Magíster en Educación Ambiental

Dirección

Mg. Diego Fernando Molano

Universidad de Ciencias Aplicadas y Ambientales U.D.C.A.

Facultad de Ciencias de la Educación

Programa de Maestría en Educación Ambiental

Bogotá. D.C

2020 


\section{Agradecimientos}

A Dios sobre todas las cosas; a mi Madre, a mis compañeros, maestros de la maestría, los estudiantes de grado noveno de la institución Ofelia Uribe de Acosta I.E.D jornada mañana, quienes participaron asertiva y de manera colectiva en la construcción de esta tesis, sin ellos no hubiera conseguido el objetivo final; a la SED Bogotá sin ellos y sus aportes a la formación de docentes que encamino el mejoramiento y avance de estudios de miles de docentes que aprovechamos los auxilios; al docente Diego Molano, quien fue fundamental en la terminación de este proyecto, al grupo de compañeros del Ofelia Uribe de Acosta que uno u otra manera aportaron en mi tesis, de igual manera para aplicar nuevos proyectos y metas no solo en la institución si no la gran construcción de ciudadanía ambiental. A la doctora María Mercedes Callejas directora de la maestría, quien siempre estuvo pendiente de sus estudiantes, los detalles, las salidas pedagógicas que resignificaron mi ayuda al medio ambiente, que apostamos y aportamos a la educación ambiental. Y especialmente a mi familia; a mi Esposa Ariadna Marcela Rubio gran apoyo en estos proyectos y metas que siempre nos concebimos para mejorar la calidad de vida de nuestro hijo Juan Sebastián Avella Rubio, que es la apuesta cada día, en proyectarme y superarme como docente y servidor público para mí país. 
Tabla de contenido

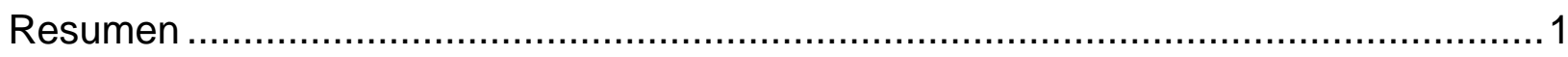

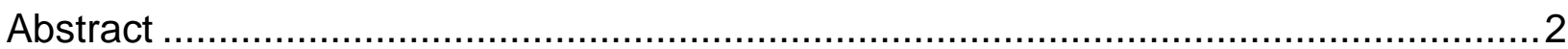

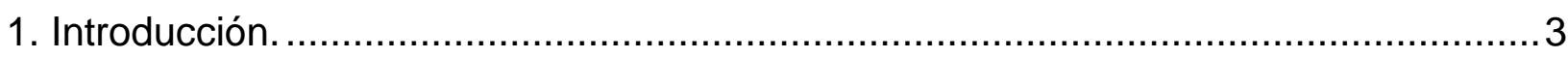

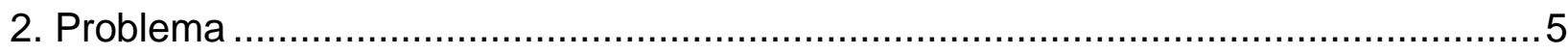

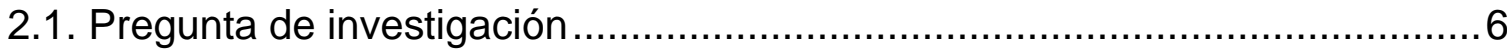

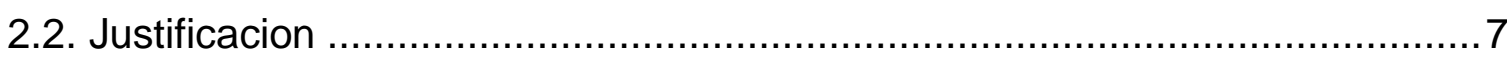

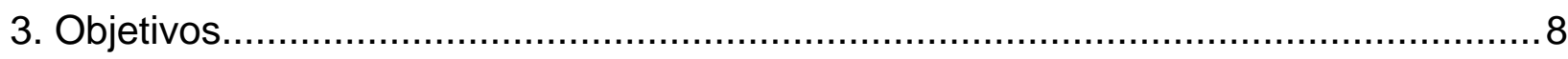

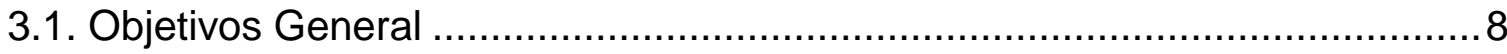

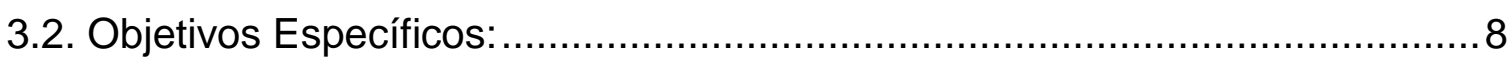

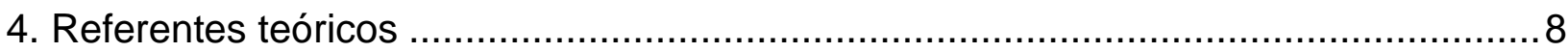

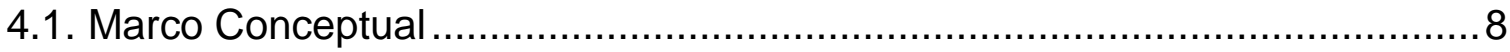

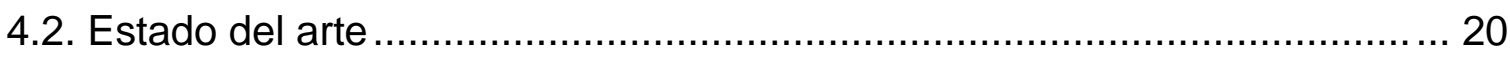

4.3. Referentes pedagógicos..................................................... 31

4.4. Componentes pedagógicas...................................................

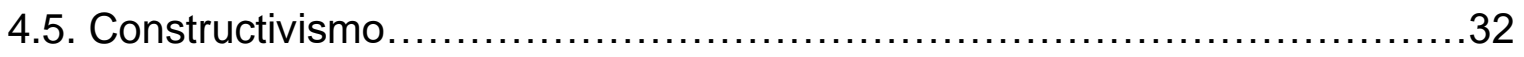

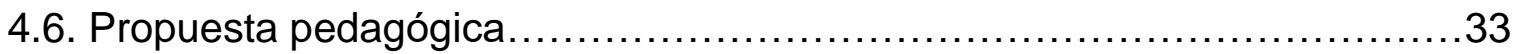

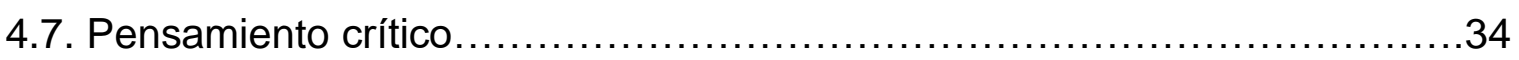

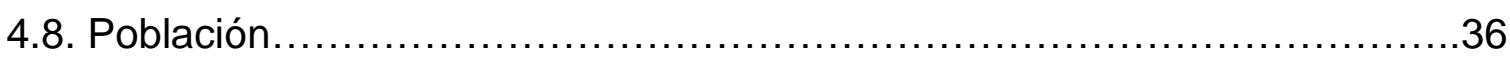

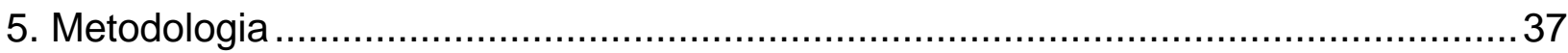

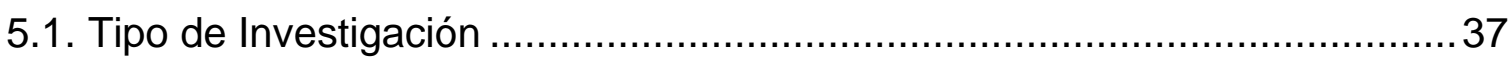

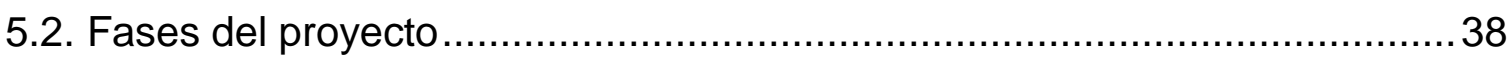

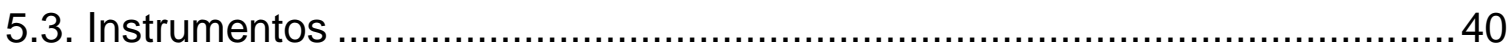

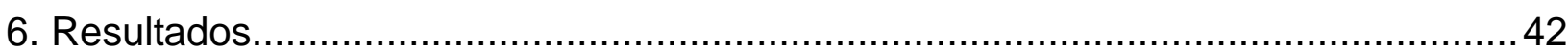

6.1. La formación de personas que fortalece la comunidad científica..............51

6.2. Construyendo Ciudadanía Ambiental......................................52

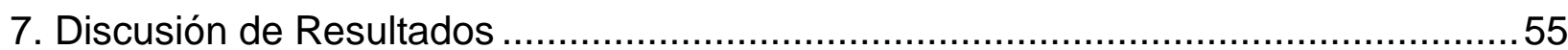

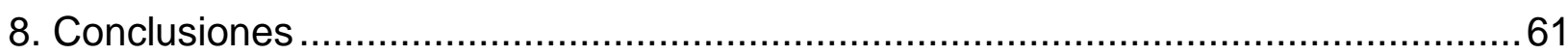




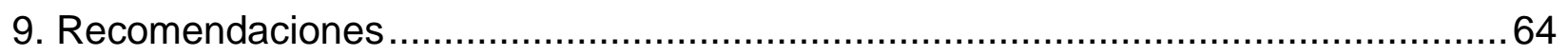

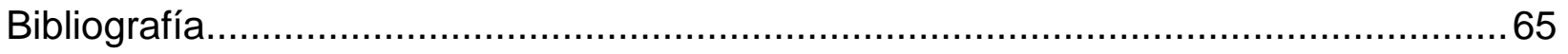

\section{Anexos}

Anexo 1. Preanálisis textos del Espectador.......................................69

Anexo 2. Campaña publicitaria protejo mi territorio..............................70

Anexo 3. Cuadro comparativo.................................................

Anexo 4. El texto de análisis es realizado entre estudiantes y el docente de ciencias

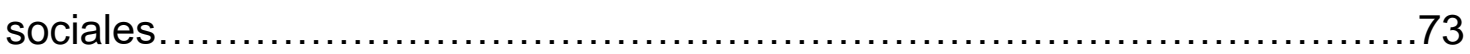

\section{Tablas}

Tabla 1. Pobreza, Desigualdad de Oportunidades y Políticas Públicas en América

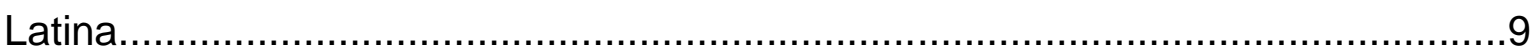

Tabla 2. Indicadores de sostenibilidad en países de la OEA ......................11

Tabla 3. Constitución de las políticas ambientales en América latina....................28

Tabla 4. Mapa conceptual políticas vs territorio....................................31

Tabla 5. Enfoques sobre ciudadanía, ambiente y territorialidad...................42

Tabla 6. Desarrollo de la propuesta didáctica......................................45 



\section{Resumen}

Muchos discursos hablan de la importancia de conocer nuestros derechos y deberes, no hay que olvidar la construcción y defensa de nuestro entorno; y específicamente del ambiente, los recursos hídricos y naturales están amenazados por la indiferencia de la sociedad actual, que permite una total desarticulación de la conciencia ambiental y los grandes problemas generados por el mal uso de plásticos, energías fósiles e infinidad de elementos contaminantes. Este hecho, lo define Murcia, 2010, al plantear:

\footnotetext{
"Así, el derecho internacional del medio ambiente y del desarrollo se caracteriza por su laxitud para con las actividades humanas susceptibles de afectar grave y acumulativamente a la naturaleza, laxitud derivada de sus cláusulas relativas a la salvaguarda al desarrollo, al principio de internalización de los costos por el daño y al de soberanía de los Estados sobre los recursos naturales" (Murcia Riaño Diana Milena, 2010, pp27)
}

Es decir, las defensa de los derechos debe superar las reflexiones que los estudiantes son generadores de una conciencia ambiental; que proteja el derecho a la vida, y por medio de las ciencias sociales generar soluciones ciudadanía ambiental, lo cual significa proteger la integridad física de las personas y su entorno.

Como objetivo del trabajo de tesis es involucrar a los estudiantes de la I.E.D Ofelia Uribe de Acosta de grado noveno, motivando trabajo comunitario, que signifique cambios de actitudes, promoviendo la acción social, ambiental y a su vez generando conciencia socio ambiental, con apropiación territorial y la conservación del mismo, buscando y analizando sus raíces ancestrales, el poblamiento de sus barrios y la llegada de su entorno familiar a la zona, que permita hoy en día motivar a crear centros de interés para sus habitantes, donde se promueve el auto cuidado y la protección general del mismo, propiciando mejores ciudadanos para que el interés sea mejorar su entorno y el cuidado de lo ambiental.

Palabras clave: ciencias sociales, educación, construcción, civismo, resiliencia, territorio, territorialidad 


\section{Abstract}

This condition shows us that we all have a large debt to the territory that saw us be born, grow or that we have lived for long periods of time. We are all designers of policies that have possible controls and of greater influence in some societies and especially environmentalists. Many authors point out relationships with CTS important elements that must be taken into account: to indicate and specify the hierarchies of the objectives and the different guidelines supported by environmental laws; most of the environmental resources have control entities, but at the same time we must train people and in my case young ninth grade IED Ofelia Uribe de Acosta, who support this project in the protection of their territory and make good use of the soil, entities and above all educational institutions, as guarantors of development processes and of assuming environmental challenges in the face of mediation of environmental policies, it is necessary to relate activities, debates, visualization of documentaries, etc.

The implementation must be carried out by entities that support their objectives of law and that consider them as highly priority, that is, to realize a dream unfounded in laws that are necessary and applicable in the area or localities where the Ophelist population lives, with a Serious objective of creating or proposing them with clear foundations for compliance, in the same way exercising control and obeying them, in turn with them generating and motivating respect, collaboration and constancy in saving the soils, the moors, wetlands and more environmental areas; that as the main object of this study is to generate environmental citizenship for young people who dreams and has goals. 


\section{INTRODUCCIÓN}

Es relevante para la educación aportar a la formación de una ciudadanía ambiental, lo cual implica considerar y abordar las políticas públicas que comprometen a las personas en la protección y preservación de su medio. Por ello, es inherente a la libertad y a la igualdad, los beneficios de proteger el entorno. A partir de la reforma constitucional de 1991: Artículo 67. La educación es un derecho de la persona y un servicio público que tiene una función social; con ella se busca el acceso al conocimiento, a la ciencia, a la técnica, y a los demás bienes y valores de la cultura. La educación formará al colombiano en el respeto a los derechos humanos, a la paz y a la democracia; y en la práctica del trabajo y la recreación, para el mejoramiento cultural, científico, tecnológico y para la protección del ambiente. El Estado, la sociedad y la familia son responsables de la educación, que será obligatoria entre los cinco y los quince años de edad y que comprenderá como mínimo, un año de preescolar y nueve de educación básica. La educación será gratuita en las instituciones del Estado, sin perjuicio del cobro de derechos académicos a quienes puedan sufragarlos. Corresponde al Estado regular y ejercer la suprema inspección y vigilancia de la educación con el fin de velar por su calidad, por el cumplimiento de sus fines y por la mejor formación moral, intelectual y física de los educandos; garantizar el adecuado cubrimiento del servicio y asegurar a los menores las condiciones necesarias para su acceso y permanencia en el sistema educativo. La Nación y las entidades territoriales participarán en la dirección, financiación y administración de los servicios educativos estatales, en los términos que señalen la Constitución y la ley. Se contempla en el artículo y 102 de la Constitución Política Nacional, «El territorio, con los bienes públicos que de él forman parte, pertenecen a la Nación». Por lo tanto, para garantizar la plena vigencia de este derecho de todas las personas, en Colombia, el Estado nacional tiene los medios para hacer cumplir la constitución, que a su vez pueda intervenir para asegurar la reparación, cuidado, auto sostenible, regulación, protección y la delimitación de un territorio sagrado y a su vez inviolable para cualquier daño ambiental.

Lo anterior está expuesto en la constitución de 1991 en el artículo 79: 
" Todas las personas tienen derecho a gozar de un ambiente sano. La ley garantizará la participación de la comunidad en las decisiones que puedan afectarlo. Es deber del Estado proteger la diversidad e integridad del ambiente, conservar las áreas de especial importancia ecológica y fomentar la educación para el logro de estos fines".

Sin embargo se presentan continuos problemas y la falta de algunos entes gubernamentales, que permite a largo tiempo continuos procesos de contaminantes; que degradan el clima y los suelos, todo esto ha sucedido por el desprecio de la sociedad, que no tiene una verdadera conciencia ambiental y necesita de manera urgente dar solución a estas problemáticas, que permitan la continua trasmisión de generación en generación, de considerar sus territorio como algo sagrado, ayudados por entidades públicas y privadas, dejando atrás las inadecuadas prácticas y el inadecuado uso de los suelos perjudicando sus formas de vida, a su vez debemos concienciar y evitar repetir la misma historia años tras años, por los mismos problemas en temporadas de lluvias que ha modificado y degradado gran parte de su medio ambiente, su territorio y la territorialidad.

En este proyecto se relaciona a los jóvenes de la institución educativa distrital del colegio I.E.D Ofelia Uribe de Acosta, grado 9o, el estrato de los estudiantes oscila entre 1 y 2 , con edades de 14 a 16 aproximadamente, la mayoría habita en la localidad de Usme; se busca a través de este proyecto tesis; la ubicación de diferentes perspectivas lógicas, casuales, críticas y teóricas la búsqueda imperiosa y en sí la necesidad de encontrar las raíces iguales o semejantes de sus ancestros, que por suerte, cosas del azar, fortuna o destino, los llevo a habitar esta localidad que puede ser muy generosa y receptiva o logra ser más cruda y agresiva, e intolerante para estas comunidades; situando a una población desplazada, desarraigados y sin un futuro asegurado en la gran urbe llamada Bogotá.

Bajo estos aspectos la educación ambiental, fue necesario observar y describir desde la enseñanza de las ciencias sociales, el reconocimiento de la sociedad como generadora de una acelerada Biodegradación de su lugar de origen, a su vez como gestor de degradación de una ciudad en un lugar invisibles para la sociedad; que muchas de nuestras generaciones, la desconoce, por lo tanto se debe construir nuevos 
procesos educativo-ambientales que generen alternativas de cambio permanentes y de conciencia de su entorno.

No olvidemos la falta de planeación, de un POT mal concebido que desde el 2004 no ha sido actualizado, y que se hace a imagen y semejanza de políticas corruptas, que someten al territorio de Usme a amenazas constantes,

"El vacío en palabras en la revisión del POT es importante en la medida de su contribución, por ausencia, al vacío real y tangible que se abre y acrecienta entre nosotros y la naturaleza de nuestro territorio, en pleno proceso de ordenamiento". (Revista de Arquitectura. 2005, pp23.)

De igual manera la diversidad y la complejidad de las ciudades nos permite que invasiones y personas irresponsables, sin educación o formación medio ambiental, se debe estar tratando de cambiar esas malas prácticas políticas, al resaltar o desmeritar las relaciones de una enseñanza constante y duradera a través de las ciencias sociales, donde los jóvenes de están logrando mejorar su educación para ser partícipes, generadores de cambio al transmitir a sus familiares lo aprendido y convertirse así en ciudadanos ambientales.

En este sentido la investigación ha querido mostrar una mayor pertinencia cultural y social ambiental, construyendo saberes que enseñan la I.E.D Ofelia Uribe de Acosta, donde el entorno ambiental hace que los estudiantes tengan más interacción con el conocimiento, en especial las ciencias sociales; es muy importante que el territorio donde estos jóvenes viven se convierta en la esperanza de todos, al conocer y divulgar los derechos ambientales que en muchas ocasiones desconocen por ignorancia y falta de educación básica o de calidad de vida, por eso se debe educar a nuestros estudiantes con sentido de pertenencia y respeto por su territorio.

\section{DEFINICIÓN DEL PROBLEMA}

El territorio de Usme se ve amenazado por las invasiones y la falta de mayor control social, que de igual manera los gobernantes, tierreros y otros que usan el territorio como propio para realizar negocios sin pedir permisos o consentimiento de las autoridades, es a la vez una enorme irresponsabilidad al dejar a miles de familias en lugares de alto riego e inestables, qué en épocas de lluvia, se convierten en 
damnificados en zonas de laderas inseguras; todo es posible en un país corrupto, sin ley y Dios.

"El suicidio de un político o de un partido político no es, como se dice estos días, votar a éste, abstenerse para que gobierne el otro o formar coalición con el de más allá, sino ser incapaz, por supuesta coherencia con unas convicciones inamovibles, de transformar las vidas de la gente, ser irrelevante para aquellos que te eligieron, no devolverles nada a cambio de sus votos". (Torreblanca José lgnacio, sep. 2016, pp 1)

Sin ningún control político, sumado a la desorganización de las autoridades de una ciudad, que cambia cada 4 años de poder, y cada uno viene con diferentes aspiraciones e inversión social o si tenerla en cuenta, que trata ayudar al desplazado o el desterrado por violencia o problemas políticos del país vecino. Viendo la imperiosa necesidad de consultar entidades gubernamentales, y permita a los pobladores de esta localidad de Bogotá, donde en este texto hay responsabilidades que ayuda a enfocarnos en formar buenos ciudadanos;

Es posible otra política. Pero en lugar de asumir responsabilidades, muchos prefieren huir de ellas. En el fondo, Rajoy no es el problema, es la excusa perfecta para que nadie, a izquierda y derecha, tenga que asumir responsabilidades. $Y$ mientras, los votantes siguen huérfanos de políticas que mejoren sus vidas. La política en España y Colombia se ha convertido en una inmensa huida adelante para evitar asumir responsabilidades. (Torreblanca José lgnacio, sep. 2016, pp 1)

Lo mismo podemos decir de Colombia y en especial Bogotá, que lo público debe ser administrado como debe ser, legal justo y razonable; para todas las poblaciones del país, sin excepción que deben ser administrados por grandes gerentes visionarios, y así evitando la manipulación de medios y que sus obligaciones debe ser social, ambiental y de servicio colaborativo, generando sobre todo conciencia y ciudadanía ambiental.

\subsection{Pregunta de investigación}

¿Cómo propiciar el reconocimiento y valoración del territorio de Usme relacionado con la enseñanza de las ciencias sociales, el respeto medio ambiental y la formación de 
una ciudadanía ambiental, en los estudiantes de grado noveno del IED Ofelia Uribe de Acosta?

Es necesario generar propuestas sobre la enseñanza de las ciencias sociales principalmente en la forma de aplicar y actuar frente a la protección del medio ambiente, los usos adecuados de los suelos, la defensa de lo público y del territorio; creando conciencia entre todos y sus congéneres. Desarrollar actividades adecuadas, asertivas en el buen desempeño y cuidado del medio ambiental, sobre todo de los medios productivos de la zona al tener un apropiado conocimiento del territorio, para lograr estos efectos muy positivos dentro de los estudiantes de noveno, al convertirse en multiplicadores, mediadores, que salvaguarden el territorio al que pertenecen y él de sus futuras generaciones.

\subsection{Justificación:}

Esta investigación ha buscado contribuir al mejor entendimiento de la enseñanza de las ciencias sociales, teniendo en cuenta el papel que juegan los saberes, los conocimientos y la percepción que se tienen sobre el ambiente, el territorio y su relación con el desarrollo humano en la construcción de sociedades justas, ambientalmente sanas, con saberes y acciones en la I.E.D Ofelia Uribe de Acosta, con una proyección hacia la ciudadanía ambiental.

Los estudiantes Ofelistas están construyendo constantemente formación medio ambiental que promueve la sana convivencia, permitiendo así la trasformación y visión de su comunidad y que por otra parte permitir la construcción de una ciudadanía ambiental y permitir la armonización de los ciudadanos con su medio social y que debe ser benévolo con el ambiente.

Esta investigación analiza la importancia de la ciudadanía ambiental en el ecosistema de Usme, que los alumnos de grado 903 sea protagonistas en la trasformación de la comunidad, como enfatiza nuestro PEI de la I.E.D Ofelia Uribe de Acosta. "La comunidad protagonista de su propio desarrollo". Artículo 6. La utilidad de esta investigación radica en la profundización del estudio acerca de esta en la defensa media ambiental en su territorio y la misma territorialidad. Esto con la finalidad de crear 
conciencia respecto su comunidad y que tienen la obligación de apoyar y contribuir a la formación de ciudadanos medio ambientales.

\section{OBJETIVOS}

3.1 Objetivo General: Fortalecer el reconocimiento y valoración del territorio de Usme a través del diseño de una propuesta educativa que vincule la enseñanza de las ciencias sociales, para los estudiantes del grado noveno, IED Ofelia Uribe de Acosta

\subsection{Objetivos Específicos:}

- Identificar los conocimientos previos del territorio de Usme de los estudiantes del grado noveno IED Ofelia Uribe de Acosta

- Implementar una propuesta didáctica en la enseñanza de las ciencias sociales que aborde el reconocimiento y valoración del territorio de Usme relacionado con las políticas ambientales en el marco de las relaciones Ciencia, Tecnología y Sociedad.

- Evaluar la propuesta educativa sobre reconocimiento y valoración de los aprendizajes de los estudiantes, frente a la protección del medio ambiente, a través de un debate, una campaña publicitaria y su relación con el territorio de Usme.

\section{REFERENTES TEÓRICOS}

\subsection{Marco Conceptual}

La apropiación del entorno y la aplicación de algunas leyes constitucionales y ambientales, debe tener en cuenta que,

"Frente al poder del estado y del mercado, la ciudadanía reclama su derecho de participar en los procesos de producción y el abastecimiento de servicios básicos, así como en la toma de decisiones que afectan sus condiciones y su calidad de vida" (Leff, 2000, pp.101).

Estas necesidades de apropiación y distribución de tierras, nos pueden convertir en personas con cierto recelo hacia la educación ambiental y la enseñanza de las ciencias 
sociales, al abordar, conocer y aplicar las leyes, en la construcción de una sociedad ambiental; para que a través de ella se pueda mejorar niveles de vida, construir, comunicar, dar bienestar y soluciones a las problemáticas ambientes, con el fin de crear zonas o espacios sanos, consolidando diferentes elementos de apropiación del territorio. El sistema político permite así integrar por ordenamiento jurídico o por las organizaciones públicas y comunales, los casos territoriales en relación con el compromiso como ciudadanos, por lo tanto, es importante conocer el POT, y el territorio donde viven nuestros estudiantes. "Los principios de ordenamiento del territorio que definió la Ley 388 de 1997 son:

"La función social y ecológica de la propiedad.

La prevalencia del interés general sobre el particular

La distribución equitativa de las cargas y los beneficios". (Parra, 2013, pp. 18)

Educar con miras a la construcción de una nueva sociedad justa y responsable con su entorno, tratando de tomar una conciencia que oriente hacia el desarrollo humano, realizando y demostrando simultáneamente causa y efecto de la sustentabilidad y de la responsabilidad, que siempre debe ser local como a su vez global, aportando ayudas económicas, beneficios en salud, educación y hasta vivienda es un compromiso desde las ciencias sociales y ambientales.

No debemos olvidar que la misma política pública es débil y no permite el 100\% de la cobertura para los que verdaderamente lo necesitan,

\section{Tabla 1.}
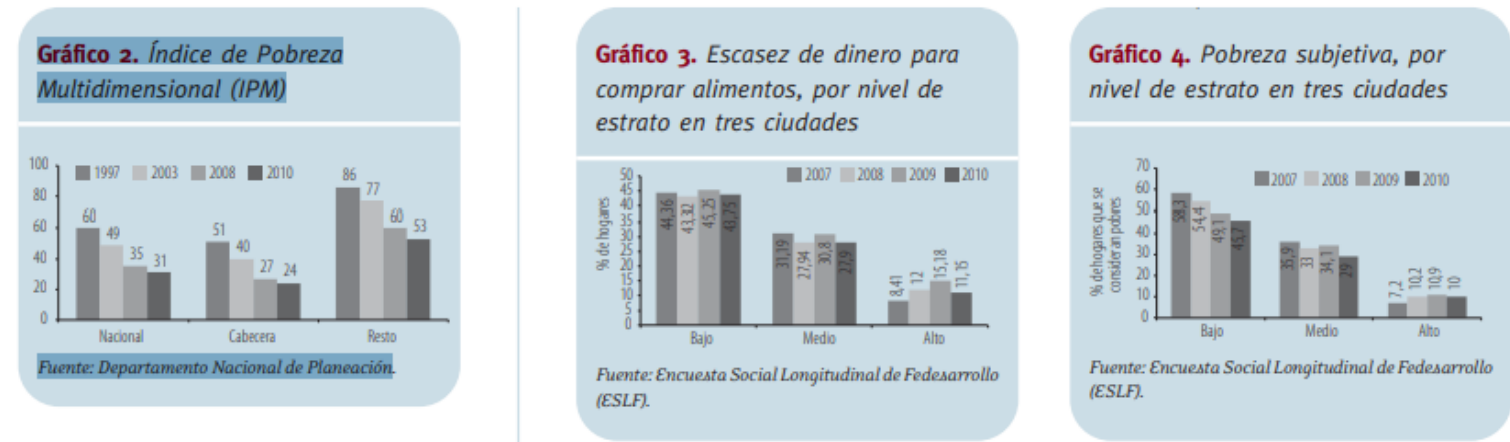

(Pobreza, Desigualdad de Oportunidades y Políticas Públicas en América Latina, Parra Torrado Mónica · Trujillo José Daniel, 2012, pp 62) 
algunos estudiantes son personas desplazadas por la violencia que fueron acogidas por residentes de estas zonas o localidades abandonadas, apartadas por entes estatales del mismo distrito, con un alto grado de resiliencia, sin prejuicios o vicios demostrado por décadas en su construcción social.

Pensar en una concertación con las necesidades de los otros es imperativo para cambiar las políticas públicas, al abordar la educación ambiental en relación con un contexto local, invita a ver el ambiente, a descubrir una realidad dada y objetiva con los propósitos de mejorar y salvaguardar el territorio de Usme: a través de la enseñanza de las ciencias sociales se propende por obtener beneficios comunes, y nunca individuales, como medio de las necesidades básicas de los ciudadanos, que buscan aprender de sus congéneres para vivir en un ambiente sano, evitando el cemento y todo lo que conlleva al progreso improvisado.

"Son pocos los países que se jactarían de contar con una institucionalidad al día frente a los desafíos de planificar e implementar políticas urbanas sustentables. Muchos, incluso, tendrían dificultades para definir con precisión lo que "sustentable" podría significar en el plano de áreas específicas de las políticas urbanas y los sistemas híbridos (humanostecnológicos) que las hacen realidad”. (Salinas Quintana Pedro, 2018, pp 222)

Es claro que el ambiente tiene una existencia real, también tiene objeciones del mundo contemporáneo, que son dependientes de múltiples saberes donde se logra por medio del ejemplo la retribución a la confianza de los estudiantes de grado noveno de la I.E.D Ofelia Uribe de Acosta; logrando que el saber ambiental se construye socialmente y condicionado por el contexto histórico, social, político, ético, etc., confiando en la hechos y realidades que ayudan a elaborar sociedades civilizadas.

La protección del medio ambiente implica un bajo costo para el estado si estuviera organizado y controlado en todo el sentido de la palabra: en lo que concierne con los dineros, los recursos naturales, y la sabia y controlada extracción de minerales, fósiles, etc. Logrando una coherencia social que puede generar y cubrir las deficiencias de los más necesitados;

"En nuestras sociedades, la esfera pública y estatal se ha instalado en todas partes, y cada individuo de un modo $u$ otro, siente sus efectos: en su vida personal, en sus 
relaciones con la colectividad, incluso en la forma de gozar de la naturaleza que lo rodea." (Ives Meny, 1992, pp. 7). A su vez genera una retrospectiva al pasado, que evidencia a lo largo de la historia de la humanidad como la educación despierta a las comunidades frente al sometimiento y control de civilizaciones o sociedades intervenidas o manipuladas, que no le permite a la población reconocer como propio su territorio y velar por su protección. Es por eso que la enseñanza de las ciencias sociales debe reconocer que

"Las relaciones ambientales y espaciales, son conocimientos propios de la geografía y la economía que permiten entender las diversas formas de organización humana y las relaciones que diferentes comunidades han establecido y establecen con el entorno natural y económico para sobrevivir y desarrollarse”. (Bobadilla, 2013, pp. 7)

Como toda sociedad el manejo del territorio y la apropiación del mismo es muy importante, ya que significa que todos hacemos parte de la localidad donde vivimos, crecemos y morimos, las raíces, las pocas oportunidades de vida que lo llevaron a desplazarse y llegar por razones fortuitas, nuevas chances de trabajo, el vivir el día a día; entre muchas razones, por eso en muchos caso es meritorio el construir una ciudadanía ambiental por las pocas oportunidades de progreso de los ciudadanos que han sido golpeados, atropellados, humillados, y que debido a su espíritu de templanza y valentía se convierten en forjadores de colectividades dinámicas y activas; al crear una sociedad sostenible.

\section{Tabla 2.}

Cuadro 3.2. Indicador de sostenibilidad ambiental para paises de la Organización de Estados Americanos y Cuba en el año 2005

\begin{tabular}{|lllllllll|}
\hline RANGO & PAIS & ESI & RANGO & PAIS & ESI & RANGO PAIS & ESI \\
\hline 1 & Uruguay & 71,8 & 9 & Bolivia & 59,5 & 17 & Honduras & 47,4 \\
2 & Canadá & 64,1 & 10 & Colombia & 58,9 & 18 & México & 46,2 \\
3 & Guyana & 62,9 & 11 & Panamá & 57,7 & 19 & Jamaica & 44,7 \\
4 & Argentina & 62,7 & 12 & Chile & 53,6 & 20 & Guatemala & 44,0 \\
5 & Brasil & 62,2 & 13 & Estados Unidos & 52,9 & 21 & El Salvador & 43,8 \\
6 & Perú & 60,4 & 14 & Cuba & 52,3 & 22 & Rep. Dominicana & 43,7 \\
7 & Paraguay & 59,7 & 15 & Nicaragua & 50,2 & 23 & Trinidady Tobago 36,3 \\
8 & Costa Rica & 59,6 & 16 & Venezuela & 48,1 & 24 & Haití & 34,8 \\
\hline
\end{tabular}

\section{1}

Fuente: (Gómez Gutiérrez Carlos, El desarrollo sostenible: conceptos básicos, alcance y criterios para su evaluación, 2016, pp 111) 
Cuya finalidad es creer en lo propio y arraigarse con templanza defendiendo con amor y decoro lo que le dio la vida y la nueva oportunidad de renacer, esta frase recalca lo anterior

"El espacio, como el tiempo, no es una realidad absoluta, real y objetiva, es una representación, son las construcciones mentales de los individuos basadas en las representaciones naturales que nos hacemos de la realidad. Así que más que de espacio como entidad absoluta debemos hablar de representaciones en el espacio." (Rodríguez, 2010, pp. 3).

De igual manera la explicación de Leff en este texto:

"Ello abre un duelo que se bifurca entre el dolor de la muerte, y la lucha por la vida,

A. De allí tres deudas y tres posiciones ante la deuda:

B. La deuda financiera: asumiendo o no asumida, pagable o no pagable, negociable, redistribuida.

C. La deuda ecológica: inconmensurable pero capaz de ser revalorizada, internalizada, redistribuida.

D. La deuda de la razón: que abre el camino del desujetamiento, de la re significación, de la construcción de un desarrollo alternativo, fundado en una nueva racionalidad productiva. (Leff, 2000, pp. 29).

Esta condición nos demuestra que la sociedad tiene una gran deuda, medio ambiental y mucho más con su territorio que nos vio nacer, crecer o en el que hemos vivido por largas temporadas de la vida; todos tenemos la oportunidad de conocer y sobre todo de aprender, por medio de la enseñanzas recibidas en las instituciones distritales, y en especial la enseñanza de las ciencias sociales, a través de medios de políticas públicas, se tienen posibles controles de mayor influencia en algunas sociedades y sobre todo los ambientalistas.

Sin embargo, estas grandes responsabilidades y retos que tiene la sociedad quedan cortos debido a que no existe una interiorización de las problemáticas ambientales y como afectan a la comunidad estudiantil, por lo tanto, se debe hacer hincapié en el papel que como ciudadanos se tiene frente al territorio y su contexto para crear una conciencia ambiental. 
En las relaciones CTS (ciencia, tecnología y sociedad) encontramos elementos importantes que se deben tener en cuenta: para indicar y precisar las jerarquías y los objetivos de las diferentes directrices apoyados en leyes ambientales. Es necesaria la formación en esta perspectiva para la protección del territorio y el buen uso de los suelos. Las entidades y sobre todo las instituciones educativas, son garantes de procesos de desarrollo para asumir los retos frente a la mediación de las políticas ambientales, es necesario relacionar actividades, debates, lecturas de artículos de prensa, visualización de documentales, etc.

La implementación debe estar a cargo de entes que apoyan los objetivos de ley y que los consideran como altamente prioritarios, es decir, hacer realidad un sueño infundado en leyes que sean necesarias y aplicables en la zona o en las localidades, con un serio objetivo de crearlas o proponerlas con fundamentos claros para su cumplimiento.

Por eso se debe dar mayor sentido de pertenencia, identificando las diferentes condiciones sociales, culturales y económicas que permitían la selección de procesos de enseñanza de las ciencias sociales y de una adecuada organización de los PEI, teniendo mayor flexibilización de los currículos en torno al medio ambiente.

De igual manera la enseñanza de las ciencias sociales, debe generar y motivar respeto, colaboración y constancia para construir una ciudadanía ambiental responsable, que ayude a salvar los páramos, humedales y otras zonas ambientales; el principal objeto de este estudio es generar ciudadanía ambiental con jóvenes que sueñan y tienen metas, para salvar un planeta que está al borde del abismo:

"la ley tiene que proporcionar oportunidades amplias para que los grupos organizados que apoyan la política puedan intervenir y participar (por ejemplo, interventorías, veedurías, monitoreo, evaluaciones) en el proceso de implementación” (Roth, 2006, pp. 203).

"La política debe disponer de apoyo activo durante todo el proceso de implementación por parte de grupos organizados de electores y por algunos concejales claves (o por el jefe del órgano ejecutivo). La actitud de los tribunales debe ser neutral o favorable. Este elemento, aparentemente fácil de conseguir, es de particular importancia cuando se trata de políticas que tienen que desarrollarse a largo plazo (varios años)". 
(Dirección de estudios socioeconómicos y regulatorios subdirección de seguimiento y evaluación, marzo de 2009)

Para que todo esto sea posible es necesario educar a los jóvenes con valores, la enseñanza de las ciencias sociales es fundamental, para entender la complejidad de las razones territoriales de los pueblos y sobre todo en esta zona, sumergida en problemas sociales y ambientales. La escuela brinda el apoyo académico y procesos de formación para construir estrategias, ayudadas por medios concretos de vida de habitantes de larga duración y constante colaboración, para generar una escuelaciudad con una realidad marcada en crear ciudadanos ambientales. Desde tiempos remotos nos hace más factible que Latinoamérica sea por una eternidad una colonia sumisa y doblegada, en la cual existen innumerables problemáticas que demarcan falta de pertenencia frente al territorio generando inequidad social, por lo tanto la escuela esta llamada a transformar pensamiento:

"la enseñanza y el aprendizaje tienen implicaciones sociales que van más allá de la medida de la adquisición de conceptos. La escuela es una institución cuya pedagogía y patrones de funcionamiento están relacionados con cuestiones más amplias de producción social y reproducción. En este contexto, la práctica pedagógica es una forma de regulación social en la que una forma particular de conocimiento se selecciona para guiar la vida diaria del alumnado" (Popkewitz, 1990, pp. 49, citado en Sandín, 2003, pp. 66)

Se cuestiona que la vida cotidiana es propensa a múltiples problemas, pero puede ser modificada para romper esquemas jerárquicos en la construcción de una sociedad más equilibrada e igualitaria, se observa en el entorno de la localidad como son degradadas las zonas de reservas, autorizadas y explotadas por gobiernos que no exigen licencias ambientales en explotación de petróleo o minera, tratando a su vez pasar por encima de las normas y leyes, educar con el ejemplo y respeto al otro es imperativo a través de propuestas pedagógicas que logren mundos posibles con una educación racional, asertiva, proactiva, de alta calidad para el desarrollo sostenible y competitivo.

Construir y reconocer más sobre políticas públicas en el país es necesario para llevar diálogos de saberes y confluir sobre ellos, con el fin de demostrar los niveles de 
interpretación en temas que pueden ser muy abstractos, hasta en los diálogos cotidianos de las personas o estudiantes motivados por conocer y tener claridad sobre problemas ambientales; motivar una construcción de ciudadanía ambiental que comprenda el saber en este campo que puede llevar a marcar una gran diferencia. Existe un alto grado de saberes en las escuelas, que se mezclan por infinidad de años, sin embargo falta una mayor interiorización por parte de los niños y jóvenes, que generen iniciativas de cambios en el cuidado y la sostenibilidad del medio ambiente, el propósito de esta tesis es potenciar una de las soluciones: enclavar en la escuela la enseñanza de las ciencias sociales, para generar cambios significativos en la comunidad en temas ambientales, donde conjugan nuevas fuerzas sociales que quieren dar su conocimiento e ignorar vertientes verídicas en llevar el saber de proteger y valorar el nivel de vida de los ciudadanos, para generar los sustentos y las necesidades como sociedad. Desde la cumbre de Estocolmo Suecia en 1972, convocada por la ONU para pensar sobre el planeta, surge la necesidad de construir, conocer y mejorar un mundo más sustentable y sostenible. Por eso y muchas más razones antes mencionadas se debe racionar así:

"La racionalidad ambiental incorpora un conjunto de valores y criterios que no pueden ser evaluados en términos del modelo de racionalidad económica, ni reducidos a una medida de mercado. Sus principios constituyen una estrategia conceptual que orienta la realización de los propósitos ambientales, frente a los constreñimientos que la institucionalización del mercado y la razón tecnológica imponen a su proceso de construcción. La racionalidad ambiental se construye mediante la articulación de cuatro esferas de racionalidad:

A. Una racionalidad sustantiva, es decir, un sistema axiológico que define los valores y objetivos que orientan las acciones sociales para la construcción de una racionalidad ambiental ( $v$. gr. sustentabilidad ecológica, equidad social, diversidad cultural, democracia Política);

B. Una racionalidad teórica, que sistematiza los valores de la racionalidad sustantiva y los articula con los procesos ecológicos, culturales, tecnológicos, políticos y económicos que constituyen las condiciones materiales, los 
potenciales y las motivaciones que sustentan la construcción de una nueva racionalidad social y productiva;

C. Una racionalidad instrumental, que produce los vínculos técnicos; funcionales y operacionales entre los objetivos sociales y las bases materiales del desarrollo sustentable, a través de un sistema de medios eficaces;

D. Una racionalidad cultural -entendida como un sistema singular y diverso de significaciones que no se someten a valores homogéneos ni a una lógica ambiental general-, que produce la identidad e integridad de cada cultura, dando coherencia a sus prácticas sociales y productivas en relación con las potencialidades de su entorno geográfico y de sus recursos naturales." (Leff, 2002, pp. 117).

Frente a las sociedades capitalistas y sus ecosistemas, son susceptibles de cambios radicales que hacen posible que la sociedad deba tener una forma más racional, radical en un país donde prima la indiferencia frente a su entorno, aguas negras generadas por basuras que la misma comunidad bota en humedales y paramos, donde las pocas zonas verdes como parques son transformadas por en cemento, desperdicio de agua, mal manejo de residuos, entre otras, conductas que se repiten a diario en el colegio y que evidencian que a pesar de los esfuerzos para impactar a los jóvenes frente a su responsabilidad frente al territorio y el medio ambiente, no transforman de manera significativa el actuar delos estudiantes para ser ciudadanos ambientales.

Antes de generar medios de protección ambiental, debemos concientizar el papel que juegan los estudiantes de grado noveno como agentes de cambio para ser una sociedad organizada, la prioridad es construir una sociedad más ambiental, fortaleciendo el papel del ciudadano a través de la enseñanza de las ciencias sociales, ganando un espacio en las actuales y futuras instituciones educativas, e igual con sus políticas ambientales se debe forjar y defender lo público, como principal objetivo de su territorio.

“Los suelos pueden agotarse rápidamente por escurrimiento de sus nutrientes y secarse por la radiación directa del sol, llegando incluso a endurecerse en forma irreversible, impidiendo la regeneración del ecosistema original y limitando severamente su capacidad productiva." (Leff, 1994, pp. 206). 
Este texto motiva al sentido de protección y construcción de ciudadanía y vigía ambiental, ampliando su espectro frente a tu territorio y su territorialidad, para fortalecer la confianza en la gente y su propia fe, que de igual manera debe generar un gran sentido de pertenecía a través de un proyecto Pedagogico que permita evaluar los procesos llevados en el aula y como permiten cambios que afectan de manera gradual a sus demás compañeros y a sus familias:

"El espacio geográfico se forma y evoluciona a partir de un conjunto de relaciones soportadas en cinco caracteres fundamentales: localizable y concreto, cartografiable, diferenciado, cambiante y homogéneo". Complementario a los caracteres señalados por Dollfus, Méndez (1988) identifica una serie de características que fortalecen teóricamente la dinámica del espacio geográfico y que son identificables con el concepto de territorio como objeto de estudio de la geografía: no ser neutral, estar originado en la iniciativa humana, ser una construcción social, ser objeto de consumo, ser funcional, ser dinámico y ser heterogéneo. (Rodríguez, 2010, pp. 4)

Esta última frase especifica que si el mundo, no está de acuerdo y unido, provocara grandes problemáticas como son la desaparición de los suelos, dejando lugares áridos sin opción de cultivos, la preservación natural y vegetal será difícil de proteger, por ello se debe generar zonas de protección ambiental, se evidencia la obtención de lugares húmedos y lluviosos para urbanización, por eso desde la escuela la enseñanzas de los maestros debe ser constante sin importar su área, en especial si forjamos ciudadanos racionales como nos dice Leff, podremos aumentar la educación ambiental de manera transversal, involucrando a toda las áreas.

Como trasformador y docente de ciencias sociales se debe asumir compromiso, y estos son recompensados en las motivaciones y el arduo trabajo realizado: ser generador de una mayor conciencia, de la mano de los jóvenes de grado noveno, los estudiantes deben ser multiplicadores y trasformadores de su territorio, para convertir zonas o sectores de degradación ambiental, en lugares amigables y amables para el hombre, ya sea para uso de vivienda, o lugares visibles a la sustancialidad y sostenibilidad ambiental, que hoy en día ya son invivibles por estar en cinturones de pobreza de las principales urbes y en especial en Usme: 
"La deuda ecológica hace emerger a la superficie la parte mayor -y hasta ahora sumergida- del "iceberg" del intercambio desigual entre países ricos y pobres, es decir, la apropiación y destrucción de la base de recursos naturales de los países “subdesarrollados". (Leff, 2014, pp. 178)

Es constante la generación de anti valores que permiten la desigualdad en los contextos escolares frente al ambiente, los cuales se convierten en Iceberg porque son muy disímiles los niveles de calidad de vida de los países subdesarrollados o en vía de desarrollo; la forma de erradicar esta inequidad es dejar las envidias regionales que desgasten a los ciudadanos en enfrentamiento banales y poco objetivos, por las diferencias abismales entre ricos y pobres, se ve muy claro que las racionalidades de Leff son aplicables en el contexto nacional, ya que los países industrializados y capitalistas han explotados por cientos de años los recursos del país, son una constante en el arraigado social y sobre todo un $100 \%$ racional, pero estas diferencias sociales y racionales en un país individualista que poco piensa en lo colectivo, evidencia un panorama que es casi imposible de conciliar, ¿qué debemos hacer para que dejemos los odios y diferencias?

"El estado de pobreza de sus pueblos no se deriva de su condición cultural o de sus limitaciones naturales - de una determinación geográfica de sus activos ecológicos- sino de su inserción dominada dentro de la racionalidad económica mundial y los procesos de colonización interna que han sobreexplotado sus recursos naturales y degradado sus potenciales ambientales en un proceso histórico de desposesión, desterritorializión y explotación". (Leff, 2014, pp. 178)

Es necesario que las sociedades actuales den mayor apropiación y sentido de pertenencia a su conocimiento científico y ambiental, dejando su subvaloración y llegando a apelativos muy fuertes y despectivos sobre la educación ambiental, donde todas estas condiciones de vida, salud, educación, trasformación y particularidades medio ambientales nos generan procesos de modificación curricular.

"La idea de des-territorialización alude al supuesto des anclaje de la cultura respecto de su vínculo con el territorio como una resultante de los procesos de cambio operados a través de la globalización, en un escenario que tiene como referencia dos fenómenos paradigmáticos: 
- La reformulación del papel del Estado como núcleo ordenador de la morfología social, con la puesta en crisis de toda una serie de nociones asociadas a la identidad nacional y su anclaje en una territorialidad estatal.

- La anulación tecnológica de las distancias de tiempo y espacio, que habilitó la problemática de las diferentes escalas involucradas en el cambio social a través de la articulación de lo local, lo nacional y lo global”. (Gómez, 2011, pp. 5)

De esta manera se debe empoderar el papel del estudiante como gestor en contante cambio y renovación, haciéndole partícipe al modificar su pensamiento y el de los demás frente a las políticas ambientales, generando iniciativas que como educadores de la enseñanza de las ciencias sociales debe valorar la educación ambiental al hacer conciencia social frente al territorio y a la territorialidad, dejando un legado a nuestras futuras generaciones. El siguiente ejemplo nos pone en contexto de la creencia de las ciencias y el currículo:

"No existe una estructura que unifique los conceptos, permitiendo a los biólogos sobreponerse a la fragmentación de su ciencia mediante una evaluación de la importancia relativa de los problemas de la investigación y el reconocimiento de la manera en que éstos se relacionan. El único esquema que utilizan para esta evaluación sigue siendo el cartesiano, según el cual los organismos vivientes son máquinas físicas y bioquímicas explicables desde el punto de vista de sus mecanismos moleculares" (Capra, 1992, pp. 63)

La mayoría de la población conoce que el manejo de los territorios de gran extensión es competencia del estado, sin embargo por la falta de entes de control y vigilancia por parte de los mismos ciudadanos, son deficientes en cuidar el medio entorno y sobre todo regular con medidas la protección ambiental, es por esto que los ciudadanos debemos tener iniciativas de regular y controlar los dineros públicos y la inversión que hace el estado en el medio ambiente, conocer los acuerdos y medidas de los ministerios para lograr efectividad y soluciones a las peticiones de la mayoría de la ciudadanía, saber en qué va a parar los aportes de los impuestos, y el PIB, y otros ingresos que son dineros públicos, es la solución a muchos problemas, para evitar que unos pocos se beneficien al degradar el medio ambiente.

"Vemos entonces que la actual pobreza se deriva de la tala de bosques, la contaminación de ríos, mares, lagunas y la destrucción progresiva de nuestros territorios 
que son fuente de vida para nuestros pueblos. Las respuestas frente a la destrucción de nuestro patrimonio de vida son, por un lado, la participación activa de las comunidades en defensa de nuestros territorios y por el otro, el mejoramiento de las condiciones de vida, desde los emprendimientos de turismo comunitario." (De la Cruz, 2007, pp. 215)

Entonces se debe a través de la educación mejorar el accionar del estudiante frente a la problemática ambiental, haciendo un buen uso sus políticas, realizando un reconocimiento del contexto del estudiante en su barrio y localidad, conocer los cambios generacionales frente a la visión del territorio, es decir potenciando los cambios positivos que beneficiaran a la comunidad en general. En los textos vistos sobre la actividad social y de enseñanza en las escuelas del país, se puede destacar:

"En síntesis, lo local -territorio- ha sido revalorizado como antídoto compensatorio y como factor complementario de equilibrio y ha supuesto que la territorialidad se reafirme como un valor emergente. Por esta razón se puede decir que la globalización -en principio tan alejada de la dimensión territorial- ha supuesto una valorización del territorio, de lo local.", (Rodríguez, 2010, pp. 8).

Para los procesos y trabajos de investigación hace posible, que se construya saberes y muchas necesidades de aprendizaje, que permite a los estudiantes de grado 903 obtener mayor soporte informativo e iniciativa propia para lograr metas y logros en la trasformación del territorio, su recuperación y la sustentabilidad del mismo, permitiendo afianzar las herramientas y trasformar su espacio con la colaboración de su familia o comunidad, de esto podemos afirmar que:

“Desde esta perspectiva, la comprensión humana es la cualidad del pensamiento que se construye poco a poco en el proceso de aprendizaje. Es imposible describir los resultados del aprendizaje en cuanto tales con independencia de los procesos. Los resultados no son más que cualidades de la mente desarrolladas de un modo progresivo en el proceso. No son especificables de antemano, normalizables, ni estados finales prefijados del aprendizaje”. (Elliot Jhon, La investigación-acción en educación2000, pp 8)

\subsection{Estado del arte}

Para el sector público la educación ambiental y la enseñanza de las ciencias sociales debe ir de la mano, ya que podemos aportar como seres sociales, razonables, ayudas y beneficios al planeta aplicando soluciones al ambiente, generando compromisos a los organismos gubernamentales: 
"Recalcamos que el desarrollo sostenible debe ser un proceso inclusivo y centrado en las personas, que beneficie y dé participación a todos, incluidos los jóvenes y los niños. Reconocemos que la igualdad entre los géneros y el empoderamiento de las mujeres son importantes para el desarrollo sostenible y nuestro futuro común". (Río de Janeiro (Brasil) 20 a 22 de junio de 2012, pp 6)

Esto nos ha enseñado la sana convivencia ciudadana y la cultura del mejoramiento, el respeto y tolerancia de nuestro medio ambiente siendo fundamentales en el progreso de una nación, que quiere surgir y lograr medios sostenibles y sustentables en naciones que solo les importa un lucro individual pero nunca un beneficio colectivo, debemos buscar medios factibles en la educación como lo expone libros o guías del ministerio de educación nacional.

En la guía número 6 "Estándares básicos de competencias ciudadanas" se clarifican las clases de competencias ciudadanas, siendo las competencias del respeto y la tolerancia frente a su medio ambiente. Desde ésta perspectiva se abordarán, a partir de referencias nacionales e internacionales algunos aspectos que se relacionan con esta investigación como son: La enseñanza ambiental como medio sostenible a las necesidades de preservar, mejorar o recuperar el medio ambiental y el aprendizaje en convivencia ciudadana, mejoramiento y estrategias pedagógicas para la preservación sentido de responsabilidad; como sentido de pertenencia al medio ambiente de la localidad 5 de Usme, todo esto puede estar explicado en pequeños apartes del libro de Enrique Leff Saber Ambiental: sustentabilidad, racionalidad, poder.

"El concepto de ambiente genera así una corriente que se va entretejiendo en las tramas de la sustentabilidad y en las trampas del discurso del desarrollo sostenible, definiendo categorías de racionalidad y del saber ambiental, problematizado el avance de las ciencias y la interdisciplinaridad, para penetrar con su visión crítica en el campo de las etnociencias, el hábitat, la población, el cuerpo, la tecnología, la salud y la vida." (Leff, 2002, pp. 11)

En el libro de "Población y Ordenamiento territorial" de la universidad Externado de Colombia,

"Se refiere a las condiciones de vida de una población determinada y a los niveles de desigualdad social existentes en función de perfiles de bienestar colectivos (acceso a la educación, salud, vivienda, seguridad social, servicios públicos, distribución de ingreso, 
etcétera), que tienen un estrecho vínculo con los aspectos sociodemográficos y económicos, y que son consecuencias de las condiciones de disparidad en el desarrollo" (Rubiano, 2003, pp. 114)

Se puede demostrar que hay herramientas de enseñanza para el sostenimiento ambiental y la enseñanza de las ciencias sociales, donde se debe prevenir el deterioro del ambiente natural para procurar proteger los parques nacionales naturales; desde las ciencias sociales se forman personas con valores, criterios y poder de determinación en prolongar la vida de sus semejantes, pero a su vez de cuidar y preservar la fauna y flora de la localidad de Usme, zona de reserva ambiental, lugar sagrado de los Muiscas, empoderando valiosos aportes de material teórico en la construcción de sanos ambientes naturales.

En el siguiente texto promueve principios de un adecuado cuidado de un recurso de difícil renovación y medio insostenible como;

“El agua es el recurso en donde quizás se muestran con mayor envergadura los problemas de la sostenibilidad ambiental de los modelos de desarrollo. Aunque en el caso del recurso agua su cantidad se mantiene más o menos constantes en la biosfera, su disponibilidad velar considerablemente en el tiempo y en el espacio, de acuerdo con las modificaciones que implica la introducción de elementos que afectan el funcionamiento del ciclo hidrológico" (Rubiano, 2003, pp. 135)

En algunos casos volver lo sostenible en insostenible para efectos del agua, prevé que los medios de arraigo y subsistencia se hace indispensable para este proyecto del cuidado y monitoreo de las cañadas y ríos o vertientes de nuestra localidad de Usme, esto denota la importancia de involucrar y motivar la participación de las familias de los estudiantes para que intervengan de manera activa en la educación ambiental. La enseñanza de las ciencias sociales tiene el compromiso de formar ciudadanos ambientales acordes a sus intereses como sociedad, generando campañas de protección por medio de la recopilación de fotos, debates, encuestas, acciones que sean palpables, como mediadores y vigías ambientales, involucrando a sus padres, hermanos, familiares y vecinos de su comunidad, motivando la participación activa que prolongue la vida de sus ecosistemas, motivando a todos los seres de las localidades de Usme y anexas, a prevenir y cuidar los lugares de paramo que ya son escasos en gran parte del país, motivando a los estudiantes a generar mayor conciencia medio 
ambiental. Para estos casos se tendrá en cuenta el tema de la diversidad ambiental y sus medios de protección, que son reguladores y constructores de sueños y metas de miles de personas.

Un aspecto importante a mencionar en la proyección es la metodología de carácter interdisciplinar, donde se establece relación entre las diferentes áreas de conocimiento, la observación y la experimentación basados en "resolución de conflictos por medio de la sana convivencia y la protección de nuestro medio ambiente" pactando dentro de la institución, un proyecto basado en programas que contiene una transversalidad: como actividades de introducción para conocer su entorno y el medio ambiente, actividades de conformación de brigadas ambientales. Finalmente, se dispone del empeño y las ganas de nuestros estudiantes y docentes, que promuevan las necesidades de la comunidad al establecer por cada actividad una tabla de desarrollo de metas, alcances o metas pendientes y que se pueden lograr.

El autor se refiere al siguiente ejemplo:

"Actores de la sociedad civil, la participación de las ONG's, las universidades, comunidades étnicas y organizaciones de base, en la gestión ambiental, le imprimen el carácter participativo y democrático con que se pretendió establecer la gestión en Colombia" (Gómez, 2005, pp. 15).

Para lograr los objetivos, se debe reconocer los entes privados y públicos a partir de su responsabilidad, compromiso y liderazgo, es crear un programa que pueda ser ejecutado con jóvenes de los grados novenos proyectado a futuro hacia los demás grados de bachillerato. Lo anterior, a partir de unas actividades construidas y apoyadas en la resolución de conflictos y de la enseñanza de las ciencias sociales como eje primordial en la tesis de grado. Es necesario construir una ciudadanía ambiental permanente y acorde a las condiciones de trabajo de las comunidades, generando oportunidades de desarrollo sostenible, auto suficiente, dinámico y modificando hacia el pensamiento social, llegando a permear razones de peso en la construcción de una ciudadanía ambiental; dirigido y evaluado de manera individual o colectiva, donde los casos de violación al medio ambiente, debe ser acompañados y denunciados para ser llevados a estancias de organismos públicos, motivando al control social, de la mano de la educación medio-ambiental y la enseñanza de las ciencias sociales. 
Desde la complejidad ambiental se plantea que para prevenir e interactuar en las diferentes formas de habitar el mundo y de concebir los procesos de enseñanza de las ciencias sociales, los ambientes deben ser sanos y acordes a lo que se merece un ser humano como un mínimo de referentes de una dignidad humana, y que en muchos casos no es ajeno a nosotros, es necesario una nueva racionalidad ambiental, donde se replanteen en profundidad los supuestos éticos y sociales. En los colegios se preparan por medio de competencias ciudadanas, y en especial, a los estudiantes, en una ciudadanía ambiental, construyendo una enseñanza acorde a los principios de la sociedad y la institución educativa. Llama la atención el diseño de algunas políticas o medidas ambientales que puede estar perjudicando la zona aledaña de nuestra institución educativa, relacionadas con el POT y la nueva forma de urbanización de la localidad, construcciones de propiedad horizontal que van trasformando las formas de vida de los ciudadanos, para ello es necesario evidenciar la importancia de generar propuestas que pueden especificar los diferentes tipos de estrategias que se emplearán para lograr una educación ambiental como lo es una secuencia didáctica, en la obtención de los resultados positivos o negativos. Por eso el apoyo debe ser constante y efectivo por parte de los estudiantes y docentes de la institución, presentes en una investigación que se puede estructurar de manera macro; en el diseño de actividades categorizadas con un fin específico como es la educación ambiental basada en la enseñanza de las ciencias sociales.

De igual forma, se confirma, lo que varios autores en temas ambientales manifiestan, la enseñanza de temas relacionados con ciudadanía, enseñanza de las ciencias sociales, la convivencia y paz; necesarias para dar una mirada transversal ya que tienen que ver con la formación en valores para proteger y potencializar la ciudadanía ambiente.

Gómez Torres (2005) plantea que las formas de proteger y cuidar el medio ambiente es crear leyes como la ley 99 de 1993, y el SINA (sistema nacional ambiental) para que con hechos y entes institucionales se pueda proteger lo que nos pertenece para vivir en un sano ambiente. Así mismo recalcar la importancia que tienen todas las personas de vivir en paz y armonía con los suyos y lo que nos rodea, como lo es la escuela y la familia en su formación ambiental. De este artículo, y de muchos más es pertinente 
la conceptualización que contiene y que puede ayudar en la construcción del marco teórico; basados en construir, actividades que pueden servir de luz para el diseño de la propuesta pedagógica que fortalecerá la institución, y que sea a futuro un modelo a nivel distrital.

"Los bienes públicos suelen agruparse por sectores. En el sector medioambiental, el bien público o la actividad ofrece calidad ambiental. Por los efectos que tienen, los aspectos de manejo y gestión ambiental se definen como bienes públicos internacionales. Los beneficios se traducen en reducción de riesgos. El bien público en el sector salud ofrece mejoras en el nivel de salud y aplica a nivel nacional e internacional. De forma similar, la paz global es un bien público internacional y las actividades que contribuyan a la seguridad y a la paz son actividades centrales" (Londoño, 2006, pp. 192)

Basados en que los bienes públicos son de todos, y en la manera segura que se utilizan de forma adecuada estos medios de trasformación social y ambiental, se insiste sobre la importancia del estudio de las ciencias sociales, es relevante para el beneficio de una comunidad que busca cuidar su entorno y los recursos que le proporciona la naturaleza, no se debe olvidar el alto grado de degradación del medio ambiente, motivados por multinacionales en el mismo consumismo, la utilización de energías fósiles, de plástico, de contaminantes que están por todo lado y en el mundo en general, lo que ha generado un alto grado de egoísmo frente a la depredación tan avanzada del ser humano, la deforestación, la contaminación, el exterminio, la depredación, el saqueo de recursos naturales.

Se debe formar seres autosuficientes, pero sobre todo pensar en eliminar en los estudiantes lo relacionado a la destrucción o desgracia de los recursos con los que se cuenta; también se debe concientizar sobre los recursos fósiles y su constante utilización, la forma de racionar al uso y su desuso; es por eso que el planeta pide a gritos la utilización de energías limpias, esto ligado a evitar la aceleración y destrucción del planeta, donde el cambio climático está logrando el exterminio de cientos de seres vivos que son ya extintos; la constante preocupación por la salud ambiental del Planeta Tierra y la posterior difusión de los problemas con un alto grado de dimensión catastrófica ambiental, es imperativa para lograr cambios en las luchas sociales, en sociedades racionales y pensantes, para lograr acciones de vida por medio de la 
enseñanza de las ciencias sociales, que debe involucrar a la comunidad internacional, donde es visible esta problemática en proporciones imaginables y de difícil control, a su vez es necesario que la misma población nacional genere cambios significativos en mediar en la destrucción, pensar que solo hay un planeta, y que debemos despertar de este largo letargo; cuando nos falte algún recurso ahí si vamos a resollar por qué no fuimos capaces de explotar lo propio; demostrar que las sociedad deben ser un progresivo desarrollo sostenible manteniendo a la escuela como pilar y agente de cambio.

Para ello, el siguiente texto da a entender argumentos que permiten tener diversas estrategias y mejoramiento, sostenibilidad y perpetuidad de los medios ambientales del país:

"La ley 99 de 1993 buscó un sistema institucional descentralizado con una cabeza coordinadora, que tuviera la suficiente jerarquía para hacer interlocución con los demás sectores, los entes estatales responsables de las finanzas y la planificación del país. A su vez las instituciones del SINA centran su misión en el manejo ambiental y abandonan las últimas funciones de infraestructura que aún desarrollaban y se adopta la definición de desarrollo sostenible como el fin de la política e institucionalidad ambiental en Colombia" (Gómez, 2005, pp. 13)

Este aspecto hace que el distrito y las institucionales distritales, puedan ser útiles para dar a conocer y acoger las leyes, mejorar la relación de la ciencias sociales como un medio de enseñanza de sus prácticas sostenibles y ambientales de la misma educación, fomentando en cualquier institución practicas sanas y elocuentes que logren medios y estrategias para cambiar comportamientos, dinamizando el conocimiento de los ciudadanos sobre las leyes y normas que por omisión perjudican la regulación de lo ambiental, el desarrollo y progreso; todo esto con eje común: lograr estudios de la relación de la enseñanza de las ciencias sociales, y lo ambiental (como interés público), la escuela como una forma de conocer los problemas del ambiente y en esa medida dar luces para el análisis de las interacciones que el conocimiento social y la defensa de lo público.

Este estudio está basado en ejemplos de sistemas privados que han sido un éxito para recordar que todos tenemos los aportes de la SED Bogotá que nos permite ser parte de proyectos ambientales, donde los estudiantes lo aplican ya sea con el PRAE, y 
el trabajo constante en la protección del territorio y la defensa de sus derechos; es necesario en la propuesta pedagógica analizar varios textos para motivar y ensayar nuevas maneras de llevar a cabo la formación de competencias ciudadanas.

Los aportes que se obtiene de este documento son el soporte teórico que genera alrededor de las competencias ciudadanas y ambientales, de igual manera, posibles estrategias de adaptación y aplicabilidad a la presente investigación como actividades, la transversalidad y la continua evaluación de los mismos. Es necesario mantener y diseñar medios que influyan y sean referentes en construir beneficios medio ambientales, que logren que la formación en competencias ciudadanas y ambientales son básicas en el desarrollo de este proyecto que tiene interés de todos y todas, al ser transversalmente lo más adecuado para la comunidad y no como uso exclusivo de la enseñanza de las ciencias sociales o de la escuela, la cual no debe ser ajena a ello "a la protección medio - ambiental".

Lo vemos en varios estudios a nivel latinoamericano:

"Seis de los países analizados, han adoptado sistemas o entidades autónomas para el control ambiental o creado ministerios con funciones específicas. En el caso de Colombia, existe un sistema descentralizado, producto de la ley 99 de 1993, conformado por un ministerio del medio ambiente, 33 corporaciones autónomas y demás entidades ambientales locales, cuyo sostenimiento se asume en gran parte por el aporte de la nación y el fondo de regalías (producto de la explotación minera), y en menor medida, por las rentas propias generadas a partir de los recursos ambientales (Gómez, 2005; Vergara-Schmalbach, 2014 pp. 12)

Para lograr el objetivo, el autor confronta a varios países latinoamericanos, con un análisis comparativo de las Políticas Públicas en materia ambiental, a Colombia la enaltece por las buenas prácticas ambientales pero que muchas veces pueden ser soportada en el papel al ser poco efectivas y activas en la realidad.

A pesar que son muchos los entes territoriales de control y regulación, se quedan cortos frente a la defensa al medio ambiente, ya que los estudios y aportes de la escuela no son claros al no existir clases o actividades que impulsen la protección de este, se considera como un espacio potencial para el descubrimiento y mejoramiento del ambiente, por medio de la enseñanza de las ciencias sociales se potencia la construcción del conocimiento e interpretación de su entorno, así como para la 
formación social se busca ejercer mayor influencia medio-ambiental, para educar a la comunidad en el respeto y la apropiación de su territorio.

Todo puede estar relacionado con muchos autores que quieren dar a entender que sus sabios consejos de la naturaleza llevan a que la problemática de depredación y degradación del ambiente, cuestione que la vida es muy valiosa y que es resaltada de manera constante:

"El saber ambiental problematiza el conocimiento fraccionado en disciplinas y la administración sectorial del desarrollo, para constituir un campo de conocimientos teóricos y prácticos orientado hacia la rearticulación de las relaciones sociedadnaturaleza. Este conocimiento no se agota en la extensión de los paradigmas de la ecología para comprender la dinámica de los procesos socio ambientales, ni se limita a un componente ecológico en los paradigmas actuales de conocimiento". (Leff, 2002, pp. 124)

Tabla 3. Constitución de las políticas ambientales en América latina.

\begin{tabular}{|lll|}
\hline País & Fecha & Creación Identificación \\
\hline Argentina & 2002 & Ley General del Ambiente No. 25.675 \\
\hline Bolivia & 1992 & Ley del Medio Ambiente No. 1.333 \\
\hline Brasil & 1992 & Código del Medio Ambiente \\
\hline Chile & 1999 & Política Ambiental para el Desarrollo sostenible \\
\hline Colombia & 1993 & Ley 99 de 1993 \\
\hline Ecuador & 1999 & Ley de Gestión Ambiental \\
\hline México & 1988 & Ley general del equilibrio ecológico y la protección al ambiente \\
\hline Perú & 2005 & Ley General del Ambiente No. 28.611 \\
\hline
\end{tabular}

Fuente: (Vergara-Schmalbach JC, Morelos Gómez J y Guzmán HL, 2014, pp. 12)

Los estudios sobre los diferentes procesos de leyes ambientales en Latinoamérica permiten evidenciar que el primer país que tomo la iniciativa fue México en 1988, sus razones, el alto grado de contaminación de unas de las ciudades más densas del mundo: su capital ciudad de México D.F; se analizaron diez países que establecieron el desarrollo de proyectos ambientales abaladas por medio de sus leyes, esto arroja que se requiere ejercer control de sus políticas ambientales, sobre todo se pueden analizar el alto grado de destrucción.

El cambio es posible con controles sociales por medio de la enseñanza de la cultura del autocuidado, como la generación de leyes que permitan regular al hombre en su afán de depredar, donde el cuidado de lo público debe ser una obligación de todos los 
gobiernos, y más del el medio ambiente, evitando la destrucción de zonas de reservas ambientales que explotan, destruyen y degradan; sin ninguna autorización, y si es necesario llevan las fuerzas públicas para dominar y controlar, pero si existiese una conciencia colectiva habría una gran repercusión social, se logra defender estas zonas de reserva como única manera de salvar al planeta.

La enseñanza de las ciencias sociales nos permite un ejercicio académico acorde a las condiciones de la normatividad del ministerio de educación, logrando expresiones de respeto y humildad en los jóvenes de I.E.D Ofelia Uribe de Acosta, para tener una visión diferente a la depredación del entorno, logrando una verdadera ciudadanía ambiental, articulando historias locales, personales y colectivas para la defensa de lo público, estos son aspectos de zonas de difícil acceso que rodean la comunidad de la institución, que pueda posibilitar su recuperación a nivel local o regional, ayudando a mejorar los medios productivos, regulando los recursos naturales para el país y el mismo planeta; por esta y muchos más razones se debe detener la degradación de grandes zonas de reservas existentes en la localidad, que pocos defienden y muchos pasamos por alto.

Pensando en un planeta vivible una de las trasformaciones para hacer, es modificar los comportamientos de los jóvenes frente a lo ambiental, crear una conciencia del territorio como eje de cambio, renovación e innovación frente a los procesos educativos de las ciencias sociales, ambientales y su responsabilidad con su entorno y el planeta. Haciendo participe a toda la comunidad de trascender en su contexto, se debe poner una apuesta a la educación ambiental, encaminada a la enseñanza de las ciencias sociales, que ha sido pensada desde los organismos internacionales y los gobiernos nacionales, para su práctica y trasformación de escuelas y colegios, que han asumido el compromiso, la responsabilidad en el desarrollo de los procesos educativo-ambientales, por eso ya es hora de cambiar, logrando un desarrollo sustentable, promoviendo conciencia ambiental fundamentalmente para el progreso de los pueblos, que resalte en la ciudadanía social medio-ambiental.

“La preocupación sobre el medio ambiente, y su consecuente institucionalización de políticas a nivel nacional, es un tema reciente en América Latina. Unos desafíos particulares, consecuencia en gran parte del desarrollo económico (como la deforestación masiva, los cultivos industriales, la contaminación de aguas, las 
catástrofes naturales y la pérdida venidera de una biodiversidad única en el mundo), son objeto de análisis por un creciente grupo de nuevos gobernantes y partidos políticos" (Vergara, 2011, pp. 10 y 11).

Para evidenciar que las trasformaciones se deben hacer desde la misma ciudadanía ambiental en su debido tiempo, no es solo exagerar o contar más mentiras, las verdades están motivadas por muchos años por la violencia, y quienes la vivimos se nos volvió costumbre, es por esto que en este corto texto evidencia la cruda realidad del país;

"Los conflictos violentos eran considerados característicos de regiones remotas, en las cuales el Estado no estaba presente (González, 1993, pp. 41). Giraban en torno a la posesión o distribución de los recursos locales, como la madera, las riquezas del subsuelo, la tierra y la producción agrícola. A falta de reglas obligatorias aceptadas por todos, los intereses contrarios chocaban con frecuencia duramente entre sí y se dirimían con la fuerza de las armas". (Internacionales, R. 1997, Análisis político, pp. 37).

Para la formación compete a entidades como el Ministerio de Educación y las instituciones educativas existen medios generadores de conciencia ambiental, es por eso que desde la escuela se debe transformar el pensamiento de los jóvenes, propiciando que las comunidades, en este caso los estudiantes, tengan un sentido de resiliencia frente a las problemáticas de su comunidad frente al entorno, el territorio y la naturaleza como patrimonio cultural, teniendo que por muchos años la violencia, es el resultado del desplazamiento y la inequidad social, no permite de esta manera que las comunidades se apropien de sus territorios y se vuelvan ciudadanos ambientales. 
Tabla 4.

\section{LAS POLÍTICAS PUBLICAS \\ Y EL TERRITORIO}

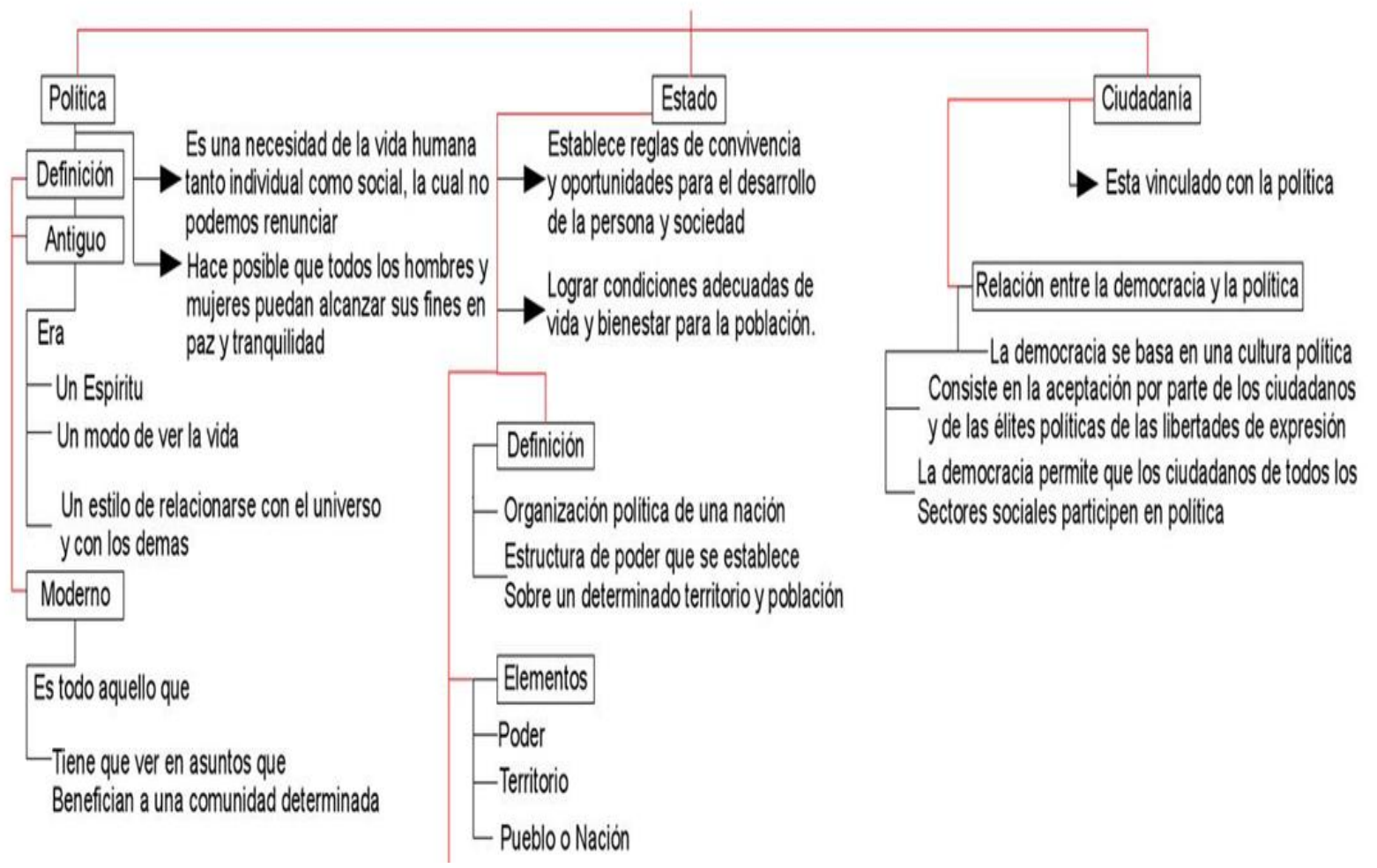

Fuente: https://issuu.com/luifer.96.13/docs/pol tica estado y sociedad peruana

Luis F. Salinas Horna

El compromiso que tiene la escuela es formar personas capaces de trasformar su entorno, la enseñanza de las ciencias sociales, genera acciones en diferentes etapas de su vida escolar y procesos de valoración al medio ambiente, al potenciar en los estudiantes el pensamiento crítico para apreciar su territorio, involucrando las competencias ciudadanas que lograran mejorar el ambiente de las futuras generaciones, al mantener las líneas de conservación para llegar más allá de los beneficios que traen algunas nuevas leyes en la protección medio ambiental.

\subsection{Referentes pedagógicos}

Los procesos pedagógicos que se enfocan en este estudio de tesis, está basado en el aprendizaje significativo, que está constituido en impulsar y utilizar los conocimientos previos de los estudiantes; para construir un nuevo aprendizaje. El docente se convierte en un guía, mediador entre los conocimientos que se aplican en la educación ambiental y su entorno, todo esto para que los alumnos tomen conciencia de su territorio y la protección del mismo, no es simplemente impartir conocimientos que pueden ser obsoletos en el desarrollo de la formación de 
ciudadanos ambientales, sino que a su vez los alumnos participan activamente con el aprendizaje significativo; construyendo conocimiento y herramientas para la protección medio ambiental; la participación del estudiante debe ser consiente de los cambios significativos para construir un mundo mejor, que les permitan fomentar el respeto por su territorio, las fuentes hídricas, el ecosistema, la fauna y la flora y la formación en valores. A continuación encontramos referentes pedagógicos con son importantes en la investigación "El aprendizaje de las ciencias sociales: Valoración del territorio por los jóvenes de grado noveno de la IED Ofelia Uribe de Acosta" para la enseñanza de las ciencias sociales desde la mirada de la apropiación del territorio.

\subsection{Componentes pedagógicos}

Este trabajo está fundamentado en la aplicación de una propuesta pedagógica basada en la enseñanza de las ciencias sociales en el grado 903 hacia la apropiación de su territorio y su territorialidad en la institución educativa distrital Ofelia Uribe de Acosta. Para la presente tesis uno de los elementos importantes es el modelo pedagógico basado en el constructivismo teniendo como eje el Aprendizaje significativo, que permite al estudiante ser gestor del proceso teniendo como base, sus experiencias y conocimientos previos para construir nuevos aprendizajes ya sea de manera individual o colectiva. Se abordaran los siguientes términos: Constructivismo, propuesta pedagógica y pensamiento crítico.

\subsection{Constructivismo}

Para Ausubel (1973) Señala en su modelo que el aprendizaje significativo es aquél en el que la nueva información se relaciona con alguna idea de la estructura cognitiva del niño y los conceptos inclusores: son aquellos conceptos relevantes de la estructura cognitiva de este. (Limas Vicente Santiváñez, 2005, pp 139)

Sumado a estos conceptos está la propuesta de la inseparabilidad del desarrollo cognitivo humano de los instrumentos de la cultura en la cual se sucede (Bruner, 1972). Las concepciones expuestas por Bruner, lo condujeron a conceptualizar sus posiciones como constructivismo simbólico. (Vielma Elma Salas María Luz, 2000, pp 36) 
Para Lev Vygotsky, el conocimiento es un proceso de interacción entre el sujeto y el medio, pero el medio entendido como algo social y cultural, no solamente físico. También rechaza los enfoques que reducen la Psicología y el aprendizaje a una simple acumulación de reflejos o asociaciones entre estímulos y respuestas. (Mariangeles Payer, 2006, pp 01)

Todo esto implica que los docentes deben poner actitudes proactivas para la localidad de Usme, de la mano de los estudiantes para planificar actividades intencionadas, sistemáticas, que logren el objetivo del aprendizaje significativo y en especial los estudiantes con mayor estímulos puede: reformular, trazar, alterar, discutir, objetar y encontrar similitudes, analizar, sintetizar, entre otras.

"El conocimiento del proceso de aprendizaje humano puede facilitar la promoción de dichos cambios. Su estudio se ha considerado fundamental en esta investigación. De ahí la atención prestada a la teoría del aprendizaje significativo propuesta por Ausubel (1968), a la que ya se hace una referencia concreta en el libro Educación ambiental: principios de enseñanza y aprendizaje". (Echarri, 2008, pp 32)

\subsection{Propuesta pedagógica}

Un elemento para tener en cuenta y de análisis es en torno a los referentes pedagógicos que están centrados en contemplar e implementar la propuesta pedagógica para educar en la ciudadanía ambiental, especialmente en el grado 903 de la Institución Educativa Distrital Ofelia Uribe de Acosta. Durante este proceso se revisará el modelo pedagógico del aprendizaje significativo; para continuar con el desarrollo de la presente investigación como es el modelo antes mencionado; bajo el enfoque medio ambiental, el cual encuadra y busca con la propuesta pedagógica y es que, el estudiante a partir de su experiencia significativas sobre la protección del medio ambiente, puedan identificar conocimientos previos que puedan generar su propio conocimiento; es decir, cada estudiante va construyendo su propio aprendizaje de manera individual y colectiva. Lo anterior permite mayor coherencia frente al grave problema medio ambiental, que se necesita mayor conciencia, determinación y sobre todo más confianza y constancia, que permita conocer elementos sobre el aprendizaje significativo, y la propuesta pedagógica que brindan mayor claridad sobre los modelos y enfoques educativos que lo encauce a ser más responsable de su autocuidado el de su 
territorio, elementos que serán claves para perfilar, emprender y apreciar la propuesta pedagógica.

"La teoría del aprendizaje significativo se centra fundamentalmente en evitar los conocimientos no comprensibles, es decir, en intentar que el educando descubra un significado a los conceptos que aprende, de manera que se puedan relacionar adecuada y coherentemente con los conceptos ya aprendidos con anterioridad, presentes en su estructura cognitiva". (Echarri, 2008, pp 32).

Finalmente, la propuesta pedagógica como instrumento educativo permite poder integrar el medio ambiente y a su vez la ciudadanía ambiental, para involucrar transversalidad del proceso de enseñanza y aprendizaje, logrando una exaltación, que debe ser retribuida en el buen desempeño de los jóvenes de 903, para que su sociedad le permita contribuir al territorio, adecuarse y apropiarse de la ciudadanía ambiental.

\subsection{Pensamiento crítico}

La relaciones humanas hacen que sea necesario que se produzca una racionalización para explicar, entender y comprender por medio del pensamiento crítico las relaciones humanas con su entorno, donde sus formulaciones aplica a que debemos entender el comportamiento humano, que sea lo racional, lo que se dice y se hace de manera clara y discreta, para no crear polémicas o vulnerar susceptibilidades; por eso se debe que su formulación sea clara a la idea del pensamiento crítico, es la que encontramos en Marx:

El pensamiento crítico (lo que Marx llama filosofía) hace "...su propia sentencia en contra de todos los dioses del cielo y de la Tierra, que no reconocen la autoconciencia humana (el ser humano consciente de sí mismo) como la divinidad suprema (Marx, 1841). (Hinkelammert Franz, 2007, pp 403)

Las razones para indagar sobre estos procesos pedagógicos es la posibilidad del descernimiento crítico, que aplica a la responsabilidad hacia el ambiente y la comprensión social sobre el territorio, a través de la formación de la ciudadanía ambiental a nivel individual y colectivo; generando una participación en procesos políticos, pedagógicos y comunitarios que conlleva a una sustentabilidad local encaminada a la territorialidad, por medio de una metodología pedagógica; con la necesidad de sensibilizar sobre el territorio; y la construcción de una ciudadanía que nos encamine a mediar por el bien general y que no aplique sobre lo particular. 
La crítica de la religión desemboca en la doctrina de que el ser humano es el ser supremo (no la esencia suprema) para el ser humano y, por consiguiente, en el imperativo categórico de echar por tierra todas las relaciones en que el ser humano sea un ser humillado, sojuzgado, abandonado y despreciable (Marx2, citado por Fromm, 1964: 230). (Hinkelammert Franz, 2007, pp 403,)

Las necesidades de buscar razones de comprender la realidad ya sea por medio de la crítica: lo científico racional o el criterio religioso, hace que el pensamiento crítico, y los aportes a saberes, sea una comprensión de paradigmas sobre realidades científica o creencias religiosas, hace que la acción participativa sea activa, formadora de una ciudadanía ambiental, que genere de alguna u otra manera las posibles realidades que contribuyan a los estudiantes del grado 903, a una toma de decisiones, y en la creación de escenarios de transformación y sustentabilidad, según su punto de vista se crea una posición de respeto a sus creencias ancestrales de los muiscas, que le permita la protección de territorios, y a la no depredación de urbanizadores o la trasformación de su localidad permitiendo el avance y el progreso para su devastación o la baja dignidad de sus habitantes por espacios más estrechos a las familias que habitan nuevos modelos de vivienda.

"Cuestiones territoriales ligadas al poder y las desigualdades, las representaciones y significaciones, la pertenencia y la identidad, las relaciones entre sociedad y naturaleza, el tiempo y el espacio unidos, las territorialidades, las espacialidades y otras están nutriendo teóricamente a la Geografía como en pocos momentos de su historia lo han hecho". (Bozzano, Horacio, 2012, pp 02)

La coherencia teórica de todos estos autores planteados en el estado del arte nos hace ver y reflexionar sobre los sanos ambientes que son posibles, en cualquier parte del mundo, pero el individualismo de los gobernantes hace imposible una equidad en todo el sentido de la palabra, que permita la construcción de ambientes sustentables, renovables, amigables y resiliente que permita mundos posibles y reales que permita a todas las comunidades a nivel mundial crear seres razonables, humanos, sostenibles y formadores de ciudadanos ambientales. 


\subsection{Población}

La Institución Educativa Distrital Ofelia Uribe de Acosta es un establecimiento Público que se encuentra ubicado en la localidad quinta de Usme en la ciudad de Bogotá, Colombia. Su P.E.I Es "La comunidad protagonista de su propio desarrollo"; cuenta con un total de 1250 estudiantes y 85 docentes orientando la enseñanza bajo el enfoque pedagógico: enseñanza del aprendizaje significativo, en las dependencias se encuentran dos sedes A y B que se divide en: preescolar, básica primaria, Básica media y Básica especializada y, su programa de inclusión en las dos jornadas mañana y tarde. Su infraestructura alberga aproximadamente 35 salones, dos salas de inglés, dos salas de informática, una sala de profesores, un laboratorio de física y otro de química, un aula de tecnologia y de música. Los administrativos cuentan con cuatro oficinas para cada coordinador; una oficina de orientación, una biblioteca, una secretaria académica, una dependencia para pagaduría, una oficina general y otra para Rectoría.

En nuestra comunidad educativa estamos desarrollando procesos de orientación para la transformación pedagógica; y los diferentes factores motivados en el énfasis del colegio el cual es en ciencias naturales y cuidado del ambiente. El colegio está emplazado en una localidad donde la mayor extensión es rural, esta localidad es Usme la cual tiene una extensión total de 21.556,16 hectáreas (ha), de las cuales 2.063,84 se clasifican en suelo urbano, 1.185,65 corresponden a suelo de expansión, 18.306,52 se clasifican en suelo rural que equivale al $85 \%$ del total de la superficie de la localidad.

El $50 \%$ de los habitantes están clasificados como pertenecientes al estrato 1 , mientras que el $50 \%$ restante se clasifica en estrato 2 . Es una localidad pobre que tiene un alto porcentaje de barrios y asentamientos ilegales no estratificados que crecen todos los días y que seguramente no alcanzan a clasificar dentro del estrato 1. Es por eso debemos resaltar que un 7,8\% de la población de Usme se encuentra clasificada en el Nivel I del Sisben, mientras que un $80,3 \%$ lo está en el Nivel II, lo que supera considerablemente los promedios de la ciudad y ubica a Usme como la localidad con mayor concentración de habitantes en estos dos niveles.

La localidad también por tener una tendencia rural, tiene gran potencial en el cuidado y preservación del ambiente, pero este contexto territorial presenta también grandes problemáticas, como por ejemplo el impacto socio ambiental del relleno - botadero 
Doña Juana, a su vez es una localidad por donde la gran mayoría de ríos o quebradas terminan siendo botaderos de basuras, vertimiento de aguas residuales, contaminantes y perjudiciales para los habitantes en la ronda de rio, siendo esta una gran desventaja por sus aguas limpias, los cuales viene siendo degradadas a cloacas o de alto contenido toxico, perjudicial para la salud en vías respiratorias y dérmicas, etc. Estas aguas son irrigadas por vertientes de origen de media y alta montaña o de paramos como el de Sumapaz; no olvidemos que la pertenecían de sus localidades es variable a sus condiciones de vida, ya sea por ser personas desplazadas de zona rurales de alto impacto de violencia, y que buscan un lugar agradable y sano para convivir.

\section{METODOLOGIA}

\subsection{Tipo de Investigación}

El trabajo se desarrolló con un enfoque cualitativo descriptivo: "La participación activa de los protagonistas del estudio, junto a los procesos de reflexión crítica y el interés por promover las transformaciones sociales, marca una de las grandes diferencias de esta metodología con otras dentro del enfoque cualitativo" (Colmenares Ana Mercedes, 2012, pp 114) que involucró varias fases, cada fase contó con cinco sesiones específicas: 1) sensibilización y apropiación, 2) profundización y estrategias, 3) conceptualización, 4) auto cuidado y protección de lo público y el último 5) reconocimiento y valoración.

Durante la primera fase fue realizada en la semana de participación de la I.E.D Ofelia Uribe de Acosta, que permitirá un trabajo grupal y a la vez individual, se implementaron dos actividades y dos lecturas, encaminadas a reconocer la localidad quinta de Usme y las problemáticas presentes sobre territorio y territorialidad, con el fin de saber cómo ubicar, reconocer y argumentar el territorio de origen y permanencia; también se tuvo en cuenta los preconceptos de los estudiantes de grado 903 y su relación con la enseñanza de las ciencias sociales.

La mayoría de los recursos utilizados fueron enseñados por los líderes del proyecto en programas curriculares del MEN, los estándares de calidad y el PEI de la I.E.D Ofelia Uribe de Acosta, se visualizó algunos videos tomados de YouTube y las relaciones en el documento \# 3 del MEN sobre las competencias ciudadana, dinámicas relacionadas 
con pensamiento crítico en inclusión del territorio entre los estudiantes de manera individual y grupal.

En la cada fase de esta investigación se desarrolló con juegos de roles, por medio de un debate que determino la protección y el cuidado del territorio, elementos importantes en ser defensor y trasgresor sobre el cuidado del territorio; para tomar conciencia y mejorar la calidad de vida de sus ciudadanos y el bienestar en general; la motivación de los estudiantes es empoderar el territorio como zona sagrada en sus relaciones educativas en su desarrollo y formación, y a su vez la participación activa y critica frente a las políticas gubernamentales; evidenciando un papel crítico y protagónico o antagónico en el debate educativo, actividad propuesta para el proyecto tesis y sobre la utilidad de este instrumentos en la investigación planteado sobre territorio y territorialidad, para la recolección y conclusión de datos, esto generó en los estudiantes la reflexión, admiración, y cambio frente al punto de vista de su territorio, es importante crear entonces otras opciones educativas centradas en un debate educativo como una herramienta de concientización.

Se desarrolló a través de cinco fases las cuales estuvieron basadas en el autoreconocimiento, apropiación de sus raíces, el reconocimiento de sus manifestaciones en los demás, cómo se ha venido poblando el barrio y la localidad, el aprendizaje de algunas estrategias de indagación con sus padres, vecinos o compañeros de curso.

\subsection{Fases del proyecto}

Fase 1. Sensibilización y apropiación: Esta fase, tuvo como objetivo conocer sí los estudiantes del grado noveno identificaban el territorio con el texto: Muiscas buscan sus costumbres frente a la occidentalización de Tatiana Molina. Buscó promover el reconocimiento del territorio que en muchos casos puede ser sagrado o tener protección estatal, construyendo territorios sagrados para el trascurrir de miles de generaciones, construyendo conciencia territorial y que de esa sostenibilidad le permita afianzar sus conocimientos, enseñar y darle importancia a lo sagrado que debe cultivarse para permanecer en el tiempo.

Fase 2. Profundización y estrategia: Esta fase del proyecto, tuvo como objetivo reconocer las causas, las reacciones que genera el territorio en su contexto 
escolar y las posibles estrategias para manejarla, en especial, las amenazas externas como una de las características de la depredación del territorio y su territorialidad, y cómo puede el joven de grado noveno llegar a vivenciarlo, pero también a manejarlo. Las actividades estuvieron enfocadas en identificar las características que vive un estudiante cuando presenta esas amenazas a nivel local y comunal que le permitieran auto reflexión de ésta y el reconocimiento hacia los demás, esto fue consultado y argumentado con la ayuda de sus padres reconstruyendo el pasado, enmarcado en la tabla 3. Así mismo, el estudiante debe hacer mayor control de su territorio, para ser un agente de cambio; relacionado con el texto: Una Amenaza en concreto de Viviana Londoño.

Fase 3. Conceptualización: Esta fase del proyecto, tuvo como objetivo reconocer las causas, las reacciones que genera estas dos lecturas: "Muiscas buscan preservan sus costumbres frente a la occidentalización" y "Una amenaza en concreto", enfocadas en estudiar el contexto del estudiante y su historia en la localidad, el reconocimiento y apropiación del territorio y su territorialidad. Anexo 4.

Fase 4. Auto cuidado y protección de lo público: esta fase del proyecto, tuvo como objetivo reconocer las causas, las reacciones que genera los problemas ambientales, la depredación, la deforestación, la usurpación del hombre y lo que puede provocar en el contexto escolar, así como las posibles estrategias para manejarlas, como son concienciar a promover la ciudadanía ambiental. Las actividades estuvieron enfocadas en reconocer los comportamientos y acciones positivas o negativas, frente al conocimiento, manejo y cuidado de su territorio; que permitieron al estudiante el auto reconocimiento de su cuadra o barrio para construir un territorio más amigable para todos.

Fase 5. Reconocimiento y valoración: Esta última etapa del proyecto se tuvo como meta reconocer aquellos estudiantes que lograron tener un cambio actitudinal en ellos y hacia sus pares, al realizar las actividades individuales como fue la auto consulta y preguntas a sus padres de familia sobre su llegada al territorio de Usme; y grupales manejando de forma positiva sus acciones para ayudar, preservar y auto regularse en su territorio y la territorialidad de Usme, por 
medio de los posters publicitarios, aplicando las estrategias aprendidas en el aula y fuera de ella. En cuanto a la valoración se evaluó el impacto logrado en los estudiantes de 903 de la I.E.D. Ofelia Uribe de Acosta, por medio de campañas publicitarias creando sus propios posters, para sensibilizar a la comunidad al reconocer su territorio que sea más auto sostenible.

\subsection{Instrumentos}

Un elemento de peso para tener en cuenta a la hora de aplicar las herramientas para recolectar datos, es contar con el contexto en el que se mueven los estudiantes y la relación que tienen con sus familias, compañeros y maestros.

El proyecto educativo "territorio y territorialidad en la I.E.D Ofelia Uribe de Acosta", estuvo determinado por los estándares educativos básicos de competencias ciudadanas propuestos (documento \# 3, 2006), por el Ministerio de Educación Nacional de Colombia, específicamente las competencias racionales y de percepción colectiva dentro de su medio ambiente, para trabajar con los estudiantes la preservación de su territorio y la protección del mismo. El otro componente del proyecto fue la mediación y trabajo de campo con los estudiantes de grado 903, donde la enseñanza de las ciencias sociales se aplica para la realización de diseños o campañas de concientización del cuidado ambiental, la preservación del territorio para conseguir un mayor sentido de pertenencia, en estas actividades los jóvenes interactuaron y realizaron actividades tendientes al manejo de sus raíces y la preservación de las mismas.

En el caso de la Institución educativa Ofelia Uribe de Acosta, es necesario la disponibilidad de los estudiantes del grado 903, cada sesión fue de 60 a 90 minutos. Las actividades desarrolladas por los estudiantes involucran lecturas acordes a los problemas ambientales, fue una forma de construir una ciudadanía ambiental.

Sobre los artículos de prensa de El Espectador, se buscó generar conciencia sobre nuevas gestiones ambientales urbanas, asequibles al medio que rodea a nuestros alumnos tanto en su lugar de origen como en la I.E.D Ofelia Uribe de Acosta, donde se propone un enfoque integral de toda la comunidad, con el propósito de articular las acciones de los diferentes actores institucionales, comunales, sectores productivos, entidades de apoyo público. La lectura sobre los Muiscas sensibilizo a los estudiantes 
frente al valor de los lugares productivos importantes generadores de cambios climáticos, el desarrollo de las áreas urbanas para fomentar el sentido de pertenencia de sus habitantes.

Los estándares mencionados son: Reconozco el territorio, implementando campañas de protección y preservación del mismo.

Expreso las necesidades del auto cuidado, y trasmitirlo a su comunidad la enseñanza de las ciencias sociales, para que tenga en cuenta la protección, resiliencia y medios legales para llevar control de posibles invasores que perjudican a la sociedad en general.

Reconozco que las acciones se relacionan al territorio en pedir ayudas o auxilios de la alcaldía local y que puedo ejercer un mayor control de su entorno y el de la localidad de Usme. Aquí corresponde hacer las mismas observaciones del proceso de investigación y el componente metodológico que permite que sea visto antes de los medios de trasformación del territorio donde viven nuestros estudiantes de Usme, lo cual es Inevitablemente, no ver los múltiples problemas del territorio y la territorialidad, para ser trasformado con la enseñanza de las ciencias sociales, en parte arte los docentes somos trasformadores de sus vidas, de actuar y construir medios sustentables a su ya desgastado medio ambiente.

Las necesidades son de constante en estas poblaciones, pero de igual manera debemos abordar una misma investigación más asertiva para que los estudiantes de 903, construyendo desde sus diferentes aspectos o facetas conduce a requerimientos mínimos de un ambiente sostenible, sustentable, racionable y amigable para toda la comunidad.

Es importante, por tanto, es la concientizar, es decir siempre podemos trabajar en un bien común, aunque cambiemos un poco de decisiones sobre la sustentabilidad, pero nunca se debe abandonar los medios y los territorios que nos acogió y que nos permite progresar y avanzar. 


\section{RESULTADOS}

El análisis de las ideas de los estudiantes hacia su territorio y territorialidad, hace que el problema enfocado sea factible y resuelva la desintegración y la falta de unidad entre la comunidad de Usme, lo cual parece ser la representación vigente por medio de actividades o guías de trabajo para involucrar a los estudiantes en medios posibles y tangibles en la adecuación de sus soluciones para proponer y aplicar lo enseñado durante el presente año, lo que permite a los alumnos obtener una visión diferente de su vida y de buscar logros y experiencias de vida adaptables a problemas, generando mejor comunicación con su comunidad, objeto de ayuda y comprensión entre vecinos y conocidos del barrio; así para lograr sueños y principalmente logrando grandes metas, obligando ver el mundo con ojos de anhelo, resiliencia y mucha esperanza; mientras que, lo que para ellos tendría sentido y este sería una enseñanza de vida y de igual valor al poderse con ayuda y comprensión de su propio mundo, en la siguiente tabla se encontrara los medios utilizados y los resultados de la investigación de tesis.

Tabla 5. Enfoques sobre ciudadanía, ambiente y territorialidad

\begin{tabular}{|c|c|c|c|}
\hline & PASADO & PRESENTE & FUTURO \\
\hline $\begin{array}{l}\text { ENFOQUE } \\
\text { SOBRE } \\
\text { AMBIENTE }\end{array}$ & $\begin{array}{l}\text { Buscar un mejor } \\
\text { futuro, salida del } \\
\text { conflicto, o querer } \\
\text { progresar en una gran } \\
\text { ciudad como Bogotá, } \\
\text { demostrar que somos } \\
\text { una ciudad sostenible } \\
\text { y amigable con el } \\
\text { medio ambiente. }\end{array}$ & $\begin{array}{l}\text { Se adecuada al ambiente } \\
\text { del barrio como solución } \\
\text { al enfoqué de estilos de } \\
\text { visión del mundo vida que } \\
\text { quieren adueñarse y de } \\
\text { implementar formas de } \\
\text { resistencia a los daños } \\
\text { ambientales. }\end{array}$ & $\begin{array}{l}\text { Es necesarios el } \\
\text { buscar soluciones } \\
\text { al mal uso de } \\
\text { elementos } \\
\text { contaminantes para } \\
\text { el planeta, el cual } \\
\text { se convierta en } \\
\text { obligación el } \\
\text { reciclar y preservar } \\
\text { el territorio donde } \\
\text { vivimos. }\end{array}$ \\
\hline $\begin{array}{l}\text { RELACIÓN } \\
\text { CON EL } \\
\text { AMBIENTE }\end{array}$ & $\begin{array}{l}\text { Principalmente los } \\
\text { medios naturales, } \\
\text { relacionados con los } \\
\text { demás medio } \\
\text { ambientales, ciudad, } \\
\text { colegio, la calle, } \\
\text { cultura, el barrio, las } \\
\text { costumbre, etc. }\end{array}$ & $\begin{array}{l}\text { Reconocer los vínculos } \\
\text { familiares, amistades, } \\
\text { diversidad cultural, } \\
\text { biológica y educativa. }\end{array}$ & $\begin{array}{l}\text { Tener siempre } \\
\text { valores y ética } \\
\text { ambiental en } \\
\text { preservar y } \\
\text { relacionar espacios } \\
\text { donde podemos } \\
\text { ver futuros } \\
\text { espacios de } \\
\text { preservación y } \\
\text { conservación } \\
\text { ambiental. }\end{array}$ \\
\hline $\begin{array}{l}\text { FORMAS DE } \\
\text { ACERCARSE } \\
\text { AL MEDIO }\end{array}$ & $\begin{array}{c}\text { Comprende el } \\
\text { problema ambiental } \\
\text { conociendo su crisis }\end{array}$ & $\begin{array}{l}\text { Establecer y reconocer } \\
\text { vínculos, con sus } \\
\text { familiares de amistad, de }\end{array}$ & $\begin{array}{c}\text { Crear formas } \\
\text { comunitarias } \\
\text { ambientales, para }\end{array}$ \\
\hline
\end{tabular}




\begin{tabular}{|c|c|c|c|}
\hline AMBIENTE & $\begin{array}{c}\text { de manera progresiva, } \\
\text { que les genero } \\
\text { desplazamiento } \\
\text { forzoso, e ir a un sitio } \\
\text { que le das } \\
\text { oportunidades de } \\
\text { vida, trabajo y } \\
\text { estudios. }\end{array}$ & $\begin{array}{c}\text { lazos de afecto y } \\
\text { construcción de una sana } \\
\text { ciudadanía ambiental. }\end{array}$ & $\begin{array}{l}\text { proteger siempre el } \\
\text { medio donde } \\
\text { vivimos, a la vez } \\
\text { ayudar su espacio } \\
\text { y su entorno } \\
\text { educativos y } \\
\text { sociales. }\end{array}$ \\
\hline $\begin{array}{l}\text { LUGARES } \\
\text { DONDE } \\
\text { OCURRE LA } \\
\text { EDUCACIÓN } \\
\text { AMBIENTAL }\end{array}$ & $\begin{array}{l}\text { Como origen del } \\
\text { progreso y el } \\
\text { desarrollo de proceso } \\
\text { ambiental, es } \\
\text { pertinente conocer e } \\
\text { identificar que los } \\
\text { estudios se inician en } \\
\text { la casa y luego en su } \\
\text { cuadra y el barrio. }\end{array}$ & $\begin{array}{l}\text { Establecer medios de } \\
\text { vidas actuales para } \\
\text { ejercer control sobre su } \\
\text { territorio para convertirlo } \\
\text { en auto sostenible, } \\
\text { sustentable y amable con } \\
\text { el planeta; enfocado en } \\
\text { las enseñanzas que } \\
\text { realizaos dentro de la } \\
\text { institución educativa } \\
\text { Ofelia Uribe de Acosta. }\end{array}$ & $\begin{array}{l}\text { Trabajo donde se } \\
\text { puede evidenciar } \\
\text { tres esferas } \\
\text { educación, } \\
\text { coherencia e } \\
\text { integralidad para } \\
\text { responder a la } \\
\text { complejidad de la } \\
\text { problemática } \\
\text { ambiental. }\end{array}$ \\
\hline $\begin{array}{c}\text { OBJETIVOS } \\
\text { DEL ESTUDIO } \\
\text { Y LA RESEÑA } \\
\text { EN LA } \\
\text { EDUCACIÓN } \\
\text { AMBIENTAL. }\end{array}$ & $\begin{array}{c}\text { Trasmitir } \\
\text { conocimiento, } \\
\text { diferentes maneras de } \\
\text { desarrollar } \\
\text { competencias medio } \\
\text { ambientales. Para } \\
\text { construir una } \\
\text { ciudadanía ambiental } \\
\text { fuerte y recurrente. }\end{array}$ & $\begin{array}{l}\text { Lograr un cambio } \\
\text { profundo en estructuras, } \\
\text { formas de vida de mis } \\
\text { estudiantes de grado } \\
\text { noveno para concientizar } \\
\text { a su comunidad y } \\
\text { apropiarse del territorio } \\
\text { de Usme y sus } \\
\text { alrededores. }\end{array}$ & $\begin{array}{c}\text { Comprender, } \\
\text { establecer y } \\
\text { evidenciar siempre } \\
\text { las causas a futuro } \\
\text { sobre la } \\
\text { epistemología y } \\
\text { racionalidad } \\
\text { instrumental, y } \\
\text { posibles soluciones } \\
\text { a las crisis } \\
\text { ambientales. }\end{array}$ \\
\hline $\begin{array}{l}\text { RECONOCER } \\
\text { SU ESPACIO } \\
\text { GEOGRÁFICO. }\end{array}$ & $\begin{array}{c}\text { Descubren un nuevo } \\
\text { mundo, diferente a } \\
\text { sus raíces para } \\
\text { apropiarse de su } \\
\text { nuevo territorio, crear } \\
\text { nuevas expectativas } \\
\text { de vida, y sobre todo } \\
\text { defender el derecho a } \\
\text { la vida. }\end{array}$ & $\begin{array}{c}\text { Con su núcleo familiar } \\
\text { tener mayor sentido de } \\
\text { pertenencia hacia el } \\
\text { territorio de Usme, } \\
\text { defender la vida de todo } \\
\text { ser vivo, vegetal o animal, } \\
\text { ser partícipe de la } \\
\text { defensa de sus derechos } \\
\text { y lo que hace parte su } \\
\text { territorio. }\end{array}$ & $\begin{array}{l}\text { Accionar en el } \\
\text { futuro el espacio } \\
\text { barrial y de la } \\
\text { localidad de Usme } \\
\text { y de su entorno } \\
\text { ambiental, para } \\
\text { que sea reconocido } \\
\text { nivel distrital y } \\
\text { nacional como } \\
\text { ejemplo de vida de } \\
\text { todos sus } \\
\text { habitantes y que se } \\
\text { sientan orgullosos } \\
\text { de su localidad. }\end{array}$ \\
\hline
\end{tabular}

Fuente: Elaboración propia

Los instrumentos utilizados permitieron recolectar datos como son: el contexto social, situación familiar, estilos de vida, pertenencia, apropiación de su territorio y del estudiante, las grandes diferencias entre sus pares del páramo de Sumapaz, los 
cuidados frente a su medio ambiente relacionado con su biodiversidad, autosuficiencia, sustentable y resiliente, el encontrar zonas sagradas de los aborígenes; que modifica un poco la forma de depredar y absorber esta zona a la gran urbe, para centrar bien el objeto estudio de la investigación.

La asignatura de Ciencias Sociales, da una formación social que apunta al desarrollo de competencias, es decir, conjuntos de nociones, estrategias intelectuales, disposiciones y actitudes que permitan a los estudiantes responder ante situaciones de su vida personal y social, en las que se involucra su perspectiva moral, de normas y leyes en una adecuada toma de decisiones, eligiendo entre otras opciones de valor, encarar conflictos y participar en asuntos colectivos, actuar y dar a conocer a las autoridades ambientales sobre algún delito, lograr alguna sanción y a su vez una retribución al daño ocasiono, resarcir la gravedad del daño ambiental en todas sus manifestaciones que implica su territorio y la territorialidad; por medio de la enseñanza de las ciencias sociales motivar a cumplimiento y el conocimiento de algunas medidas

"Se trata que los territorios, sus actores, sus problemas y las formas de resolverlos sean útiles a las Instituciones y a la sociedad en general. Una concepción de territorio -como espacio socialmente construido teóricamente sólida y de amplio alcance en los objetos de investigación y a la vez en los objetos de intervención, son pilares en el entendimiento, la inteligencia y el desarrollo Territorial". (Bozzano Horacio, TERRITORIOS : EL MÉTODO TERRITORII. 2009, PP 02)

que permitan actuar frente al incumplimiento de cualquier sentencia al daño ecológico o medio ambiental; que afecte la vida y la honra de los animales y especies naturales, obligando a cumplir una labor social que permita indemnizar el daño ocasionado y permita una vida digna a nivel medio ambiental.

El desarrollo de competencias ciudadanas expuesto en el (documento \# 3 del MEN); genera una demanda y a su vez un ejercicio práctico, tanto en situaciones de la vida diaria como personal e independiente; construyendo una sociedad más colectiva, con mayor atentación contra el mal uso de los recurso naturales, incluyendo nuevas herramientas educativas para nuestro territorio; analizando algunos desempeños de los estudiantes de 903, para llegar a un feliz término de esta tesis, apoyado en estudios y relaciones abiertas; valorando, motivando con normas y leyes; que identifique de alguna 
manera la justa valoración del territorio y su territorialidad. Las reflexiones sobre tan importante juicio moral y de las leyes como de igual manera, son también de las herramientas básicas del quehacer cotidiano; atento con la toma de decisiones, llevado a los centros de conciliación si es posible, o a instituciones regionales como La Secretaría Distrital de Ambiente, la CAR, etc. para lograr ser un individuo activo, pro activo, que permita solventar el daño medio ambiental, de esos actores que comenten un grave delito medio ambiental en el territorio de Usme.

\section{Tabla 6. Desarrollo de la propuesta didáctica.}

\begin{tabular}{|c|c|c|}
\hline ACTIVIDADES & DESCRIPCIÓN & OBSERVA \\
\hline $\begin{array}{l}\text { 1. Debate: encaminado } \\
\text { como parte de la } \\
\text { defensa de lo público, } \\
\text { con respecto a } \\
\text { salvaguardar el medio } \\
\text { ambiente y su territorio } \\
\text { de Usme, apoyado con } \\
\text { el docente en la } \\
\text { defensa del páramo de } \\
\text { Sumapaz. }\end{array}$ & $\begin{array}{l}\text { Analiza problemas } \\
\text { particulares dentro del aula } \\
\text { y los acontecimientos } \\
\text { locales, nacionales y } \\
\text { asume una actitud de } \\
\text { respeto; interioriza y valora } \\
\text { el uso de sus propios } \\
\text { juicios de valor respetando } \\
\text { el actuar propio y de los } \\
\text { demás, se toma } \\
\text { decisiones personales } \\
\text { congruentes con los } \\
\text { valores que practica en su } \\
\text { ámbito ambiental, escolar } \\
\text { y social. }\end{array}$ & $\begin{array}{l}\text { Objetos de aprendizaje. } \\
\text { - Juicio moral de } \\
\text { castigo o de perdón } \\
\text { - El problema ético, } \\
\text { moral y ambiental } \\
\text { - Decisión, congruencia, } \\
\text { pensamiento y acción, } \\
\text { porque lo defiendo y lo } \\
\text { juzgo. } \\
\text { - Libertad, honestidad, } \\
\text { igualdad, prudencia y } \\
\text { justicia que implica que } \\
\text { todos tengamos } \\
\text { condiciones para } \\
\text { ajusticiar o dar } \\
\text { sentencia a algo o } \\
\text { alquien. }\end{array}$ \\
\hline $\begin{array}{l}\text { Construyendo ciudadanía } \\
\text { ambiental por medio de } \\
\text { debates, donde promuevo } \\
\text { el salvar el páramo, el rio, } \\
\text { el bosque, la playa, el mar, } \\
\text { los océanos, e ir en contra } \\
\text { de la basura y la } \\
\text { degradación de lo natural. }\end{array}$ & & \\
\hline 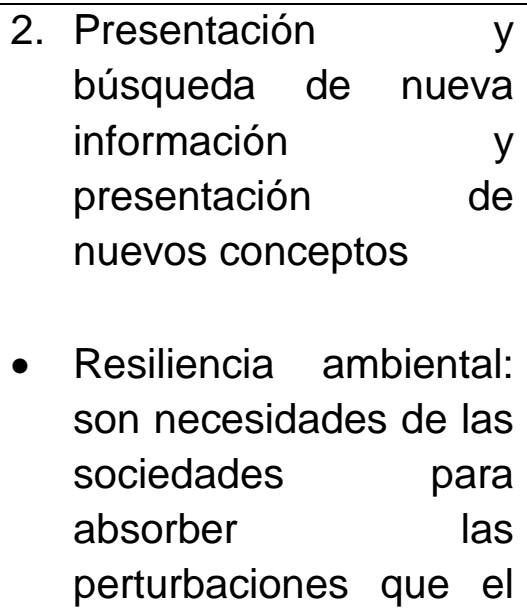 & $\begin{array}{l}\text { Lean los artículos } 78,79, \\
80,81 \text { y } 82 \text { de } \\
\text { la Constitución política de } \\
\text { Colombia de } 1991 \text { que } \\
\text { establece el derecho al } \\
\text { ambiente para todos los } \\
\text { habitantes de la República } \\
\text { de Colombia. Sobre estos } \\
\text { artículos se debe descifrar } \\
\text { en que afecta, los } \\
\text { derechos constitucionales }\end{array}$ & $\begin{array}{l}\text { - Con la información } \\
\text { recopilada del cuadro } \\
\text { anterior evidenciar las } \\
\text { leyes relacionadas con } \\
\text { problemas medio } \\
\text { ambientales en nuestra } \\
\text { comunidad Ofelista en } \\
\text { el barrio que resido. } \\
\text { - Por medio de la } \\
\text { enseñanza de las } \\
\text { ciencias sociales, }\end{array}$ \\
\hline
\end{tabular}




\begin{tabular}{|c|c|c|}
\hline $\begin{array}{l}\text { hombre ocasiona al } \\
\text { medio ambiente. }\end{array}$ & $\begin{array}{l}\text { relacionados con las dos } \\
\text { lecturas } \\
\text { mencionadas. }\end{array}$ & $\begin{array}{l}\text { aplica el término de } \\
\text { resiliencia ambiental. }\end{array}$ \\
\hline $\begin{array}{l}\text { Debemos ser conscientes } \\
\text { de otros seres que nos } \\
\text { acompañan en los } \\
\text { procesos de vida y que } \\
\text { hacen parte de la cotidiana } \\
\text { del hombre, me respeto y } \\
\text { respeto a mis animales. }\end{array}$ & QUE & \\
\hline & & \\
\hline ACTIVIDADES & DESCRIPCION & OBSERVACION \\
\hline $\begin{array}{l}\text { 3. Construyo y evidencio } \\
\text { las necesidades de mi } \\
\text { comunidad, dando } \\
\text { inicio a procesos medio } \\
\text { ambientales en jóvenes } \\
\text { que son vigías } \\
\text { ambientales, por medio } \\
\text { de comics realizar } \\
\text { conciencia ambiental. }\end{array}$ & $\begin{array}{l}\text { Analicen los listados y } \\
\text { entre todos elaboren una } \\
\text { debate entre los } \\
\text { estudiantes de noveno y } \\
\text { con la colaboración de sus } \\
\text { docente, generar una } \\
\text { defensa razonable y } \\
\text { justificable con el gran } \\
\text { daño ambiental que } \\
\text { genera las } \\
\text { multinacionales, políticos o } \\
\text { los llamados cacaos del } \\
\text { país, genere una lista de } \\
\text { acciones que pueden } \\
\text { llevar a cabo en la escuela } \\
\text { y en sus hogares para } \\
\text { cuidar el ambiente. } \\
\text { Elaboren un afiche para } \\
\text { dar a conocer estas } \\
\text { acciones y preséntenlo en } \\
\text { una cartelera de la } \\
\text { escuela. Para realizar el } \\
\text { afiche pueden utilizar la } \\
\text { herramienta CTSA } \\
\text { disponible en sus lecturas } \\
\text { y textos sugeridos. } \\
\text { Actividad fotos al final } \\
\text { anexo audiovisual. }\end{array}$ & $\begin{array}{l}\text { - } \text { Presentación y } \\
\text { búsqueda de nueva } \\
\text { información y de } \\
\text { conceptos básicos en } \\
\text { la defensa de la vida y } \\
\text { el sagrado derecho a } \\
\text { una vida digna, libre de } \\
\text { contaminación: } \\
\text { auditiva, audiovisual, } \\
\text { polución, tráfico etc. } \\
\text { - La enseñanza de las } \\
\text { ciencias sociales hace } \\
\text { posible de mundos } \\
\text { posibles, con ayuda de } \\
\text { los jóvenes de grado } \\
\text { noveno, aplicamos } \\
\text { soluciones al territorio y } \\
\text { las necesidades } \\
\text { fundamentales para } \\
\text { mejorar niveles de } \\
\text { vida. }\end{array}$ \\
\hline $\begin{array}{l}\text { Incentivar los buenos } \\
\text { hábitos de cuidar el } \\
\text { ambiente, y todo lo que } \\
\text { nos rodea, la basura } \\
\text { nunca es buena, mata el } \\
\text { ser y lo envenena, } \\
\text { construir } \\
\text { ambiental por medio de } \\
\text { comics, que genere } \\
\text { conciencia ambiental } \\
\text { desde temprana edad. }\end{array}$ & & \\
\hline
\end{tabular}




\begin{tabular}{|c|c|c|}
\hline ACTIVIDADES & DESCRIPCIÓN & OBSERVACIÓN \\
\hline $\begin{array}{l}\text { 4. Difundir/ o dar a } \\
\text { conocer por medio de } \\
\text { videos las dificultades } \\
\text { de otros para salir } \\
\text { adelante, buscando el } \\
\text { bienestar colectivo. }\end{array}$ & 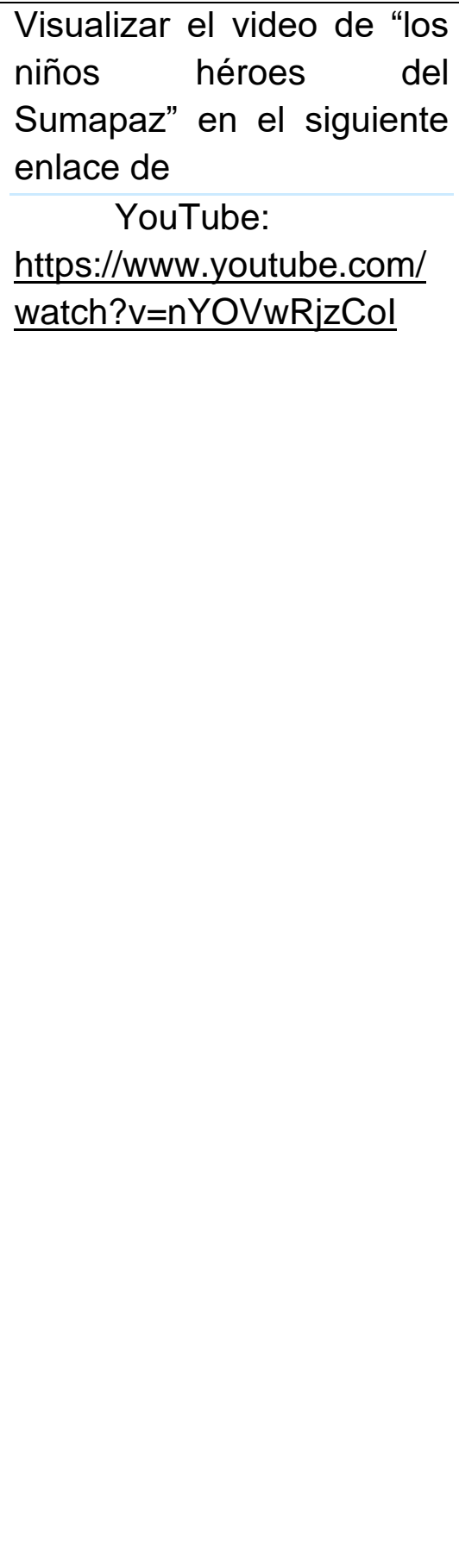 & $\begin{array}{l}\text { - Luego de verlos } \\
\text { comparen los dos videos } \\
\text { que elaboraron antes con } \\
\text { las respuestas que se } \\
\text { dan en el video a la } \\
\text { pregunta: « ¿qué } \\
\text { podemos hacer para } \\
\text { respetar el medio } \\
\text { ambiente?». Si lo } \\
\text { consideran necesario } \\
\text { completen el listado a } \\
\text { partir de la información } \\
\text { que conocieron en el } \\
\text { video. } \\
\text { Entre todos, conversen } \\
\text { sobre cuáles son las } \\
\text { situaciones que ya } \\
\text { provocan o pueden } \\
\text { provocar daño ambiental } \\
\text { en el barrio o la I.D.E } \\
\text { Ofelia Uribe de Acosta. } \\
\text { Hagan la lista de esas } \\
\text { situaciones y propongan } \\
\text { acciones para reparar o } \\
\text { evitar el daño ambiental; } \\
\text { por medio de una } \\
\text { exposición de fotos } \\
\text { regula y controla los } \\
\text { daños medio } \\
\text { ambientales en los } \\
\text { alrededores del colegio } \\
\text { l.E.D Ofelia Uribe de } \\
\text { Acosta. Debate. }\end{array}$ \\
\hline $\begin{array}{l}\text { Construcción de mundos } \\
\text { posibles, donde lo más } \\
\text { importante es destacar las } \\
\text { diferentes formas de vida } \\
\text { en los páramos del país, } \\
\text { generando conciencia y } \\
\text { ser parte de los vigías o } \\
\text { guardianes de lo público y } \\
\text { lo medio ambiental. }\end{array}$ & & \\
\hline ACTIVIDADES & DESCRIPCIÓN & OBSERVACIÓN \\
\hline $\begin{array}{l}\text { 5. Elaboración de una } \\
\text { Campaña publicitaria, } \\
\text { como una manera de } \\
\text { defender su } \\
\text { comunidad, la defensa } \\
\text { del territorio y sobre } \\
\text { todo ser guías de la }\end{array}$ & $\begin{array}{l}\text { Organicen una campaña } \\
\text { publicitaria para difundir, } \\
\text { en la I.E.D Ofelia Uribe de } \\
\text { Acosta y entre la } \\
\text { comunidad educativa, el } \\
\text { significado y los alcances } \\
\text { de los derechos y políticas }\end{array}$ & $\begin{array}{l}\text { - Para organizar esta } \\
\text { campaña publicitaria, les } \\
\text { recomendamos seguir } \\
\text { estos pasos. Primero, } \\
\text { definan el nombre a la } \\
\text { vez un eslogan, que sea } \\
\text { muy llamativo y llame a }\end{array}$ \\
\hline
\end{tabular}




\begin{tabular}{|c|c|c|}
\hline $\begin{array}{c}\text { enseñanza de las } \\
\text { ciencias sociales, se } \\
\text { motiva para realizar } \\
\text { varios posters con un } \\
\text { eslogan, que sea muy } \\
\text { llamativo y llame a la } \\
\text { reflexión. Se seleccionó } \\
\text { "Recorriendo la } \\
\text { memoria histórica de } \\
\text { Usme", }\end{array}$ & ambientales. & $\begin{array}{l}\text { la reflexión. Se } \\
\text { seleccionó "Recorriendo } \\
\text { la memoria histórica de } \\
\text { Usme", Luego, es } \\
\text { conveniente que se } \\
\text { dividan en grupos de } \\
\text { trabajo y cada una } \\
\text { asuma diferentes } \\
\text { responsabilidades. } \\
\text { También es conveniente } \\
\text { que establezcan un } \\
\text { cronograma para los } \\
\text { distintos momentos de la } \\
\text { campaña publicitaria por } \\
\text { medio de redes sociales } \\
\text { con el apoyo de medios } \\
\text { electrónicos para: inicio, } \\
\text { difusión, elaboración de } \\
\text { materiales, lugar de } \\
\text { realización, finalización, } \\
\text { que sea garantes de } \\
\text { iniciativas educativas } \\
\text { para convertirse en } \\
\text { públicas y respaldadas } \\
\text { por medio del gobierno } \\
\text { nacional. }\end{array}$ \\
\hline $\begin{array}{c}\text { Generando compañas } \\
\text { medio ambientales con } \\
\text { mis estudiantes de } \\
\text { noveno, para retomar la } \\
\text { sana convivencia, la que } \\
\text { nos sostiene y nos permite } \\
\text { vivir, por largas } \\
\text { generaciones, evitando así } \\
\text { contaminación generando } \\
\text { conciencia ambiental. }\end{array}$ & & (N) \\
\hline
\end{tabular}

Esto significa un trabajo en equipo que fue aplicado durante el año escolar que significo un absoluto sentido de pertenencia; y creando un macro universo, donde territorio es una infinidad de posibilidades; generando principalmente conciencia ambiental, modelos de vida razonable, sostenible, autosuficiente, saludable, determinante y constructivo para respetar el territorio y la territorialidad; con el presente estudio se consigue un aporte con mayor compromiso medio ambiental hacia su localidad, a sus necesidades y la construcción de una ciudadanía ambiental responsable, objetiva y asertiva; y por medio de la razonabilidad, dar un sentido común a la conciencia ambiental, para promover en la comunidad más sostenibilidad y mayor 
resiliencia, que influya y permita ser modelos sustentables, autocríticos y autosuficientes; donde sea un ejemplo no solo a nivel local, si no distrital; motivados a generar cambios, estilos de vida, colectividad acorde a construir ciudadanía ambiental. Es decir los jóvenes necesitan preferiblemente cambiar hábitos y rutinas de vida, de construcción de sociedad, de consumo responsable, razonable y un adecuado conocimiento de algunas políticas públicas actuales;

"Los "territorios reales" son aquellos objetos de una instancia descriptiva en nuestros trabajos. Se refieren a realidades reconocidas en los territorios, no necesariamente elegidas ni consensuadas por todos; responden al qué de los territorios, a preguntas tales como ¿qué componentes analíticos integran el territorio? ¿Qué rasgos permiten entender el territorio, el lugar, la ciudad, la región u otro recorte territorial? Los territorio reales son preferentemente analíticos, están expresando un aspecto de la compleja realidad: el uso del suelo real, el relieve, la población, las infraestructuras, la hidrografía, los equipamientos, las necesidades básicas insatisfechas, el tamaño de las explotaciones agropecuarias, etc". (Bozzano Horacio, territorios: el método territorii. 2009, pp 06)

y que de fondo y trasfondo genere y trasforme las formas de pensar en el acelerado cambio climático; y sobre todo aplicar el ambientalismo sostenible y razonable, y que a su vez, permita la generación de mejores niveles vida, que está sustentado en calidad ambiental llevadero, defendible y lo más importante con un gran sentido de resiliencia; que sea adecuada y sana, con posibilidades de vivir con menos preocupaciones, generados por las talas de bosques indiscriminadamente, el arrojo de papeles, contaminación de ríos, quebradas, lagos, lagunas, humedales, zonas de reserva, paramos, para evitar así el consumo de energías fósiles, el no saber reciclar, (debemos ser la conciencia colectiva y comunitaria, educativa, trascendental, sincera y con sentido social y ambiental). Sobre todo, es significativo que los jóvenes debe influir masivamente a tener mayor sentido de pertenencia y de su propia realidad; que motive las formaciones y trasformaciones con sentido social, académico y ambiental, esperando ayudar a comprender la vida para vivir en paz y armonía, sin recibir nada a cambio; todo los gestos territorio ambientales, son para gozar los procesos educativos con la ayuda de la enseñanza de ciencias sociales, que nos ayuda a ser constantes, servidores del cuidado de lo público, evitando y solucionando problemas, desarraigo, 
abandono de las alcaldías y ciudadanía en general con el principal objetivo de mejorar calidad de vida, apoyo mutuo, constante y permanente dejando atrás la desesperanza.

La construcción debe ser de manera constante, motivando los análisis críticos y de comportamiento de los estudiantes; que pretenden avanzar y generar hechos frente a su proyecto de vida y que ellos mismos se debe generar libertad en los cambio de un caudillaje y el dominio de algunas sociedades, en especial con un comportamiento social y esencialmente ambiental para proteger su territorio y ser un verdadero ciudadano que trasforma para ser más: progresista, constructivista, con un énfasis de pensamiento crítico y aprendizaje significativo, para que la sociedad se reinvente con la guía de Paulo Freire que construye y recupera su voz que se alza frente los cambios climáticos; : "La práctica educativa es todo esto: efectividad, alegría, capacidad científica, dominio técnico al servicio del cambio", sostenía Freire", www.resumenlatinoamericano.org.

Es construir el futuro de la educación popular como concepción general de la formación integral y autónoma de cada estudiante de la I.E.D Ofelia Uribe de Acosta; que es felizmente aplicable con dedicación y constancia, la cual la enseñanza debe ser siempre e incluyente y que sigue inspirando experiencias en el mundo y en nuestro continente, sobre todo sus obras que genera, desarrollo y progreso en distintas direcciones y se debe conocer, compartir, difundir y destacar; creando ambientes sanos y sobre todo proteger el territorio como su último bastión de vida.

El territorio debe ser un componente ético y político que presume igualdad, la fraternidad, la lealtad, el respeto y el compromiso, y que no debe admitir abusos de autoridad y que se apropien de su territorio, donde NO debe existir límites y que lo trunquen, ni que provoque prejuicios relacionados con su territorialidad, respecto a raza, religión, clase, e infinidades de casos que conlleve a transgredir a los ciudadanos por territorios propios y que se convierte en sagrados desde tiempos ancestrales, con la base de una sana soberanía; que debe ser precisa y participe de una ciudadanía ambiental, libre y soberana de todo su medio de vida; en algunos caso de dura subsistencia, para que no sea cuestionable, respetado a todos sus derechos y deberes. El territorio es un arma noble que educa desde la esencia humana y puede contribuir a 
hacer realidad de utopías, sueños y vehículos de convivir en armonía con su medio ambiente, la sociedad y principalmente su territorio, y que a su vez posibilite un mundo mejor.

\subsection{La formación de personas que fortalece la comunidad científica}

Es un momento crucial donde las políticas públicas están trabajando fuertemente en fortalecer el territorio y que tenga relación con estamentos locales, regionales y estatales, es así como la escuela juega un papel importante para dar a conocer a toda la comunidad educativa, las leyes ambientales que son las principales herramientas y conlleve a mejorar e incluir de manera directa los medios para manejar el territorio, que permita en lo posible de manera directa o indirecta a padres de familia, acudientes, personal administrativo, directivos y demás maestros donde estamos dando espacios para que los niños y jóvenes conozcan sus derechos y deberes; para que sea aplicable a través de las competencias ciudadanas, y principalmente el referente de una ciudadanía ambiental responsable y justa con toda la comunidad que rodea la institución educativa.

Como principal medida y como medio de reflexiones generales podríamos decir que construir ciudadanía ambiental es esencial en la articulación de una pedagogía actual y contemporánea, transformadora, sostenible e incluyente, y además es una base de igualdad y protección para todos los proyectos humanos, inmersos en gran parte de nuestra cotidianidad y en los ambientes escolares, para ser más sostenible los ambientes cotidianos con sentido práctico como garantía de preservación, de continuidad, de posibilitar cambios según el contexto histórico, de mantenimiento de tradiciones culturales y el reconocimiento de su territorio desde su óptica y la historia de la zona; descubriendo un diálogo de saberes que permita relaciones horizontales entre los diferentes grupos, ya sea a nivel micro y macro.

El territorio se convierte en el punto de encuentro donde se construye conocimiento y se legitima el mismo dentro de la diversidad de realidades en las que se edifica y se rehace necesariamente de transformar la escuela y que todos interactúen por el bien de nuestros estudiantes. La territoriedad es un componente social, propio de su idiosincrasia que supone la igualdad, la fraternidad, la lealtad, el respeto y el 
compromiso, y que no debe admitir invasores, delincuentes, tierreros, etc.; para esto debemos proteger, limitar y deliberar, por los mismos prejuicios relacionados con raza, religión, clase; aunque sí es preciso tener en cuenta estas cuestiones para respetarlas en todos sus sentidos. "El diálogo de saberes y el territorio es un arma noble que educa desde la esencia humana y puede contribuir a hacer realidad las utopías posibles y un mundo mejor" (Bobadilla 2008, pp. 111)

Es por eso que debemos dialogar, construir lugares de manera cordial y civilizada, no con egos o saberes que puede humillar o apabullar la ignorancia, la mala educación y la incomprensión de seres de un territorio delimitado, es por eso que es necesario desarrollar un proceso "interactivo-educativo" que nos permita a los estudiantes y docentes; a conocer y aplicar los medio geográficos, donde exista medios o posibilidades de zonas trasformada de mejorar su territorio ayudados con la normatividad, logrando seres educados y que desarrolle una enseñanza equitativa, incluyente y civilizada, que nos admita a los docentes en general en ser generadores de cambios y trasformaciones, desarrollando una labor voluntaria, gratificante y convencido de transformar vidas y de estas que podamos salvar su territorio con mayor control para ejercer un espacio vital de vida.

\subsection{Construyendo Ciudadanía Ambiental.}

Un poco de este aspecto que es bastante particular; están en las prácticas educativas en la escuela con la enseñanza de las ciencias sociales, vale la pena plantear una definición del territorio y la que está más cercana a la evaluación de los procesos comunitarios en el desarrollo y el plan de cuidar los medios ambientales en una adecuada apropiación del territorio expuesto en la territorialidad; es necesario formular un juicio valorativo y consecuente con el territorio de Usme, sobre la actuación de cada individuo o colectiva de individuos o en un curso de acción, nosotros como institución educativa debemos programar o generar una realidad educativa sostenible, autosuficiente y resiliente, como comunidad debemos ser amable con el territorial. Esta definición permite que observamos un hecho o varios procesos de actividades académicas que con el trascurrir del tiempo tiene un carácter subjetivo bastante marcado y tal vez por eso la evaluación educativa presenta muchas dificultades en la protección del medio ambiente y su importante relación del territorio en Colombia. 
Si bien la educación obedece a unos propósitos de ciudadanía ambiental, también es cierto que se han quedado en la simple visión de calificar el poco trabajo realizado en comunidad, de igual manera es medir los avances o progresos en que se enseña a los estudiantes; debe ser necesario construir ciudadanos ambientales críticos y proactivos en su desempeño de vigías ambientales; que son nuestros principales bastiones de recuperar la memoria ambiental y la misma apropiación del territorio. Esto por lo general se enmarca que el territorio como un medio de protección ambiental y de igual manera construir una ciudadanía ambiental; que su apropiación del mismo nos hace unos seres proactivos en mejorar mi calidad de vida y de la comunidad a la cual todos pertenecemos.

Es necesario una transformación ambiental que permita mejorar la enseñanza de leyes o normativas ambientales; que no sean tan acartonadas que el propio sistema educativo donde enseñamos de manera repetitiva el mismo discurso una y otra vez, debemos enseñar por medio de una interdisciplinaridad institucional,

Una visión prospectiva que permita vislumbrar el futuro de forma objetiva debe tener en cuenta diversos datos, bajo un mismo nexo: fijos y flujos... Así nos daremos cuenta, en el mismo movimiento, de las posibilidades ya realizadas en lo real y de las que se mantienen en reserva. Debemos entonces recordar que, si lo real es lo verdadero, lo posible es siempre mayor que lo real y el futuro más amplio que lo existente. (Bozzano Horacio, Territorios: el método territorii. 2009, PP 09)

donde todas las áreas y ciclos sean partícipes de conformar nuestros ciudadanos ambientales en distintas ópticas, con diferentes realidades y motivaciones para crear seres participes y proactivos de su propia realidad.

Desde luego también desde una mirada más objetiva y sistemática, para obtener más información detallada de la legislación ambiental y su normatividad en Colombia; no como un simple requisito de reconocer su realidad, puede lograr mejorar o contribuir a salvar su comunidad y a tener mayor sentido de pertenecía frente a sus raíces y medios que lo llevan a ser seres permanentes en el territorio como vigías ambientales y que deben tener un deber primordial de construir zonas seguras, amables, flexibles para cuidar el futuro de las siguientes generaciones; nuestro territorio debe convertirse en un medio de apropiación de su bienestar y calidad de vida; y que nos ayude tanto a 
los estudiantes, padres y docentes a mejorar en los aspectos de la enseñanza medio ambiental, es desde luego que sea valioso observar en donde están las fortalezas, pero también donde las debilidades y las fallas.

Uno de los inconvenientes que se observa en el territorio, es el problema del enfoque, socio ambiental que plantea fundamentalmente tres medios o interacciones para el manejo del territorio en el país. La primera es en los análisis de elementos dentro del contexto de territorio y de territorialidad, donde la parte más influyente en este aspecto es la memoria urbana y la familiar, por ello se resalta el papel en cuanto a estos análisis parten de las relaciones que hay en el ámbito escolar y como cada una de estas relaciones impone o influye a la hora de abordar la evaluación y el significado del territorio. Es decir, una cosa es las relaciones humanas y otras la sociedad organizada y con un claro objetivo de la vida y el territorio, que muchas veces no nos ponemos de acuerdo y llegar a posibles acuerdos.

El segundo elemento es observar las líneas que influye o provoca la inestabilidad del territorio y que se debe dar un proceso evolutivo, las razones son porque en cada relación muchas veces, ahí más valoración a ciertos elementos que otros, la actitud en clase, la información adquirida, la construcción del conocimiento, el desarrollo de procesos, la misma participación y comportamientos humanos que promueven el progreso, el orden y la paz mundial, pero desgraciadamente son más los problemas y la cruda realidad. Es por eso que en muchas ocasiones se da mayor peso a las evaluaciones internas como externas; que a unos o algunos aspectos de la vida cotidiana que necesita apropiarse de su terreno y de la localidad que lo ha cobijado durante muchos años, es para ellos gran parte de su vida.

Y el último elemento que resalta es el territorio como un medio productivo, pero a la vez es saber explotarlo y cuidarlo en el fortalecimiento de los vigías ambientales que ha recibido capacitaciones en el buen uso del terreno y así evaluar de forma sistémica; donde los factores exclusivo de la calidad de vida de nuestros estudiantes, nos lleve a mejorar factores ambientales como son las condiciones de agua, del aire, que son parte primordial del bienestar humano que caracterizan del medio físico nos deben garantizar la seguridad a mejorar una vida social, 
"La evaluación de estas circunstancias implica tomar en cuenta la capacidad tecnológica para afrontar las condiciones adversas. El clima, el relieve, los riesgos naturales forman parte de un entorno que es difícilmente transformable pero que puede ser tratado para alcanzar mayor o menor bienestar y para mitigar el riesgo ante amenazas naturales" (Rubiano; 2003, pp. 115-116),

y que otras manifestaciones en la naturaleza forman parte de un entorno que ya es la evolución socio ambiental y hace parte de una realidad problemática en la escuela, se hace necesario analizar muchos elementos y como cada uno de ellos constituye una parte esencial para afrontar este proceso, como es su ciudadanía ambiental.

\section{DISCUSIÓN DE LOS RESULTADOS}

Pensar en currículo de alto o bajo impacto en nuestras instituciones educativas, nos hace más propensos a mejorar o declinar de la calidad educativa, es por eso que el principal saber de todo educador; es ser conocedor de su localidad o territorio y poder buscar las fallas que son constantemente sistemáticas en el sistema educativo distrital y nacional, pero a su vez debe tener una mejor percepción educativa, social-cultural, económica, política y territorial, saber qué en él: educador puede ser un gran colaborar, revolucionario y generar cambios de alto impacto ambiental, que puede promover y concienciar los sentimientos de pertenecía, apropiación del territorio y el compromiso socio-ambienta; para luego sentir y comprender las organizaciones y los procesos de enseñanza y aprendizaje de donde desarrolla, solucionando y mejorando la percepción al mundo y sus necesidades como individuo y comunidad.

Como principal objetivo de esta tesis es cumplir las metas y objetivos trazados en la educación formal y no formal en la construcción de una ciudadanía ambiental, donde debe cumplir unos estándares educativos o simplemente con unos pre requisitos que exige nuestro ministerio de educación nacional, donde se comenta de esta manera:

"La Política Nacional de Educación Ambiental muestra resultados de integración entre distintos entes desde el Ministerio hasta las ONG, pasando por las Corporaciones Autónomas Regionales, y a diferentes niveles. Asimismo, es expresión de que continuidad y claridad en el objetivo producen resultados en materia de calidad, para el 
ambiente, para la educación y para el país". Tomado página web ministerio de educación.

El cual la gran mayoría de los educadores debemos ser un ejemplo de construcción en sociedad y transformación de una ciudadanía ambiental, pero no siempre los sueños son una realidad que puede ser parcial o total, lo son catastróficos por infortunios de la misma comunidad, que se debe apoyar y trasformar su mundo de problemas, atrasos y desaciertos; somos y seremos generadores de principios tantos éticos y morales, de una construcción en ciudadanía ambiental y superando con hechos y acciones de honestidad, con un alto grado de ética profesional o el oficio en el cual se desempeñe, haciendo visible los currículos, que en muchos casos complican la enseñanza justa y adecuada para su entorno, que debemos transformar cada día más enseñanzas o historias de vida de nuestros ancestros o antepasados, logrando conexiones básicas en un entorno de medidas políticas impuestas a lo largo de los siglos; ineficientes, obsoletas o si algún sentido, que son más laxas que drásticas, que no comprenden las necesidades de los ciudadanos que quienes ejercen una constante productiva de su entorno, que pueda ejercer una sana y correcta ciudadanía ambiental.

La mayoría de las políticas públicas deben enfatizar, lograr y apropiarse de mejoras herramientas con la ayuda audiovisual, y sustentar los logros de la geo-sociedad ambiental; que pueden ser apropiadas por personas de muy pocos recursos, pero de igual manera deben generar logros continuos y proactivos; para solventar y generar confianza en toda la comunidad, donde todos los ser humanos están buscando algo como: "una felicidad continua y perpetua". De la misma manera todos los seres humanos somos diferentes, contradictorios, problemáticos, etc.; $Y$ entender un poco sobre el raciocinio, se debe involucrar medidas para salvar esos sueños, o de lo contrario esas metas, objetivos o propósitos deben ser guiados por ciudadanos que pueden dar la vida por su medio socio-ambiental; que debe recibir una educación ambiental sólida, constante y trasparente. Esta cita que resalta el rol del maestro y dice:

"Los maestros necesitan de los investigadores como los investigadores necesitan de los maestros. Entre el cambio pedagógico y el trabajo de investigación existe una relación más fundamental que la que se expresa en la comprensión de la experiencia de 
los maestros por parte de los investigadores. Se trata de la relación entre esa comprensión compartida del proceso que se vive en el aula y las transformaciones de ese mismo proceso: comprender lo dado es abrirse a lo posible; conocer es cambiar" (Hernández, 2005, pp. 16)

En general debemos asumir una forma distinta de la noción humana, y que el investigador debe ser un educador, y el investigador promover y generar una mejor formación, capacitación y construcción de herramientas en curriculares flexibles y claros para una gran población universal; porque a lo largo de los procesos educativos; los investigadores tiene una concepción de la vida, que en algún momento provocan envidias y presunciones que controlan saberes de una forma propia y ausente para la comunidad en general, sin importar de quién? Puede ser subjetivo o desproporcionado algunos escritos plantean:

"Uno como investigador se cuestiona sobre el grado de certeza y la posibilidad de validar o, por lo menos, poner sobre el tapete lo propuesto. El futuro tiene la posibilidad de alcance y de construcción, ciertamente que el pasado narrado probablemente ha ocurrido tal y como nos lo cuentan, con alto grado de acercamiento a la verdad, pero también con un elevado nivel de incertidumbre". (El tiempo: secreto de la investigación, 2008, pp.31)

lo que puede dar su conocimiento, o como se hace propietario de conocimientos que nunca son divulgados, el solo hecho de dominar conocimiento y que puede cambiar el mundo o la concepción de este, todo esto para someter débiles e inofensivo seres faltos de la educación; que pueden conducir a conseguir personas que quieren tener más conocimiento y facilidades en adaptarse a los ritmos de construir sabiduría, pero existen investigadores que al ser respetados y que pueden disponer de una libre conciencia y provocar avances que pueden trasformar el mundo actual y futuro. Muchas razones nos obliga a todos a construir el currículo, se puede convertir en un pretexto para lograr más conocimientos, de trasformar, modificar y crear más mundos sustentables, sostenibles, solubles y prácticos para nuestro medio ambiente, es el momento justo de la historia de la humanidad para conseguir mayor prestigio, necesario para concientizar al docente y a su entorno educativo, porque al investigar se convierte 
en una poderosa herramienta de proteger sus interés y sus doctrinas epistemológicas, así se ve reflejado en esta pequeña cita:

"Dos aspectos permiten mostrar cómo llevan a cabo la investigación cualitativa los maestros. El primero, alude a la manera como, según ellos, se logra la construcción de conocimiento dentro de este enfoque y el segundo a los diferentes tipos de investigación que pueden adscribirse al enfoque cualitativo, de los cuales pueden derivarse aprendizajes en términos de problemas formulados, construcción teórica, trabajo de campo y desarrollo metodológico (unidades de observación -o casos-) y recolección de información) y conclusiones o resultados comunicados". (Hernández, 2005, pp. 112).

Viendo estas iniciativas por parte del texto de navegaciones, nos hace cuestionar que el currículo no lo es todo, y que puede ser modificada para romper esquemas, procesos sistemáticos, jerárquicos y en la construcción de una sociedad más equilibrada e igualitaria, pero no olvidemos que el docente puede ser manipulado, que al no construir conocimiento se hace más propenso a desaparecer y ser remplazado por otros, o en casos extremos por situaciones sociales, éticos, morales, jurídicas o del mismo sistema, que puede imponer reglas de manera absurda con decretos o sanciones.

Podemos encontrar muchas cosas frente al currículo, donde el docente puede ser utilizado o abandonado según sus intereses, ya que muchos espacios el currículo menos precia al sujeto ambiental, que puede reglamentando al interés de la institución escolar, que ni hace presencia sobre el medio ambiente, en su sentido obligado al PRAE, pero para ejercer control, monitoreo, presencia estatal o distrital es mínima, y que en muchos casos es por cumplir con el cronograma del colegio, pero en función del cuidado del medio ambiente se sujeta al área de ciencias naturales, casos constante en la mayoría de las instituciones distrital, que de la misma manera está sometido la I.E.D Ofelia Uribe de Acosta. Se puede evidenciar lo antes mencionado en el siguiente segmento de texto:

"La creencia en la ciencia excede ampliamente cualquier cosa que las ideas científicas nos permitan realizar. Por lo tanto, la relativa pérdida de confianza epistémica en la ciencia que impregnó toda la segunda mitad del siglo XX fue paralela a un auge de la creencia popular en la ciencia. La relación entre creencias e ideas con respecto a la 
ciencia, ya no es una relación entre dos entidades distintas sino que es una relación dos modos de experimentar socialmente de la ciencia. Esta dualidad significa que el reconocimiento de la diversidad cultural en el mundo no necesariamente significa el reconocimiento de la diversidad epistemológica en el mundo" (Boaventura de Sousa Santos, 2010, pp. 51).

De igual manera es un gran reto el construir un nuevo currículo, o implementar nuevos esquemas para crear ciudadanos ambientales, como nos lleva a que el currículo es un medio para generar procesos de transformación social, que confluye que el medio educativo para forjar conciencia ambiental, y llegar a esto se debe conocer currículos articulados a planes de sostenibilidad y sustentabilidad, que en un principio debe interesar la transversalidad del sistema educativo, y no convertir a las escuelas en islas, o instituciones de papel que solo les importar llenar formatos o documentos que los articule a sociedades auto sostenibles y sustentables. Leyendo algunos textos veo que la ciencia puede ser la materia que trasforme el pensamiento humano, pero de igual manera sea ciudadanos ambientales que construyan su sapiencia en pro de la comunidad de Usme y en espacial a los alrededores de la institución educativa, analizando el texto de Sousa vemos premisas para resaltar como lo hace el siguiente texto:

"Una de las premisas básicas de la ecología de saberes es que todos los conocimientos tienen límites internos y externos. Los internos están relacionados con las restricciones, en las intervenciones del mundo real impuestos por cada forma de conocimiento, mientras los limites externos resultan del reconocimiento de intervenciones alternativas posibilitadas por otras formas de conocimiento. Por definición, las formas de conocimiento hegemónicas solos reconocen límites internos; por lo tanto, la exploración de ambos de los límites internos y externos de la ciencia moderna tan solo pueden ser alcanzados como parte de una concepción contra hegemónica de la ciencia" (Boaventura de Sousa Santos, 2010, pp. 53)

Son muy difíciles los planes o proyectos de personas de bien, y que se puede evidenciar los múltiples problemas en la actualidad, que tiene varias opciones: o vivimos o aportamos; o quitamos o desafectamos; estamos inmersos en infinidad de temas polémicos que puede involucrar a los más pobres en cinturones de miseria como lo explica esta frase: 
“La concentración y crecimiento de la población en condiciones de pobreza en las áreas urbanas puede ser explicada por procesos simultáneos: de una parte, la inmigración de población precarizada de zonas rurales o de ciudades de niveles inferiores, de otro, el empobrecimiento de población residente en las áreas urbanas que al no lograr articularse al sistema productivo, se ve disminuidas sus condiciones de vida y reducidas las posibilidades para competir con la población que asciende socialmente y con aquella que ingresa de manera forzada desde las regiones periféricas, y finalmente por la mayor tasa de fecundidad que alcanzan los hogares urbanos en condiciones de pobreza" (Ciudad, espacio y población, 2017, pp. 41).

Uno de los puntos álgidos de esta tesis es la descripción que hace sobre la actitud y disposición de algunas estudiantes en su quehacer constructivo y argumentativo, ya que en algunos con bajo interés y participación limitó contundentemente el objetivo de la investigación; esto llama la atención ya que si no existen parámetros y acuerdos para aplicar un proyecto en una institución sin contar con todos los entes que participan en un proceso pedagógico contando con las dificultades son enormes y a sus vez hace que el estudio realizado con ellos se debió enfatizar el sentido de pertenecía del territorio y como apropiarse de esa territorialidad, el cual se verá reflejado en los bajos resultados, por la falta de colaboración de ellos mismos y en especial la poca o nula ayuda de sus padres para percibir un poco los orígenes y su destino final frente a la apropiación de este territorio que ya es propio, y no de extraños. 


\section{CONCLUSIONES.}

Es necesario ser transformadores de conciencias, de seres con sueños y metas, no olvidemos que si hay muchos procesos de cambios, de innovación en zonas de alto indice de subdesarrollo y que por el constante desplazamiento interno, genera migraciones; que conlleva a tener más competencia y menos opciones de oportunidades de estudio, trabajo, salud, vivienda, etc. cambiar estos estilos de vida que en muchas ocasiones son forzadas y que culminar etapas sin cumplir metas.

Es evidente a la hora de crear los instrumentos de aplicación en la etapa de diagnóstico deben ser bien estructurados bajo las categorías extraídas de los objetivos específicos; las alternativas de solución son muchas, pero hay casos específicos que podremos confrontar, de generar cambios el chip y decir en el pueblo emana el poder y de él se debe respetar, logrando así mayor equidad y beneficios y de ello obtener mejores niveles de vida. ¿Será que estamos por el buen camino en obtener los beneficios y la pócima mágica de las políticas públicas?

Por esto está investigación nos lleva a concluir que se deben propender medios y situaciones recurrentes a la mejora de la apropiación del territorio, a través de una ciudadanía ambiental, donde todos debemos construir una sociedad, tolerante, igualitaria, incluyente e influente en todos los procesos de saneamiento y motivación para recuperar, fortalecer y convertir estos espacios en lo más sostenible en Usme; apoyados en experiencias significativas que dejan una enseñanza para permitir aproximar a la comunidad a ideas y personas que han trabajado en crear espacios 0 recuperarlos con amor, templanza, dedicación y sobre todo con pasión, por ultimo no olvidemos los beneficios para los estudiantes y sus familias.

En la investigación realizada frente a sus problemas o soluciones de vivir en un territorio de paz o guerra, puede concluir en referencias de mejorar la calidad de vida, dejar atrás la desigualdad, generar mejores ciudadanos ambientales y territoriales que nos involucre a todos los medios tanto propios o ajenos, logrando en mejorar el bienestar colectivo, en aspectos sociodemográficos y económicos, equidad de servicios frente a los altos estratos, y mayor desarrollo sostenible frente a su territorio y él que va acumulando la ciudad por la alta demanda de emigrantes; esto obliga a nuestros ciudadanos ambientales o estudiantes, que vivan un mejor nivel de vida, apropiarse de 
su territorio, construya en la unidad, con mayor sentido de pertenencia, arraigo a lo propio ese que se construyó con sudor y sangre; dejar los extremos, por culpa del desplazamiento, desarraigo, o por propia voluntad o por algunos casos, de familiares o allegados que vienen siendo vecinos de una gran localidad, que vive de su sostenibilidad y que da grandes frutos, al que llega y se enamora de ella.

"El territorio se redefine siempre." Entre los cinco tipos de territorios, se trata ésta de una particular definición de territorios pensados, sin embargo, está totalmente integrada a los otros territorios: reales, vividos, legales y posibles". (Bozzano Horacio, (2009) Territorios: el método territorii. pp 10)

Todo esto podría tener un gran potencial en el ámbito educativo, pues el hecho de generar conciencia con las personas que habitan el estructura del proyecto territorio es aun así, el mismo potencial que podemos construir sueños no individuales, sino colectivos donde influya su posición geopolítica, y a la vez que incluyan un bienestar influyente, incluyente, de una gran resiliencia y sobre todo una gran construcción de ciudadanía ambiental.

Una de las maneras de construir y reinventar el tipo de argumento para contestar de manera honesta y clara sobre sus territorio, territorialidad y el de otros, se consideran que la población ubicada cerca de la institución educativa, tienen ciertas ventajas sobre su vida, y la dignidad que se maneja frente a otros seres de la localidad o las vecinas; estos privilegios o ventajas son abismales con los niños del campo o las veredas vecinas sobre la apropiación del territorio y el proyecto de vida, en la ejecución de sus medios de súper vivencia, resaltan los sacrificios de los niños de lugares apartados, sobre todo ellos son como todos los ciudadanos ambientales; está el proyecto de tesis que genera la construcción de ciudadanos medio-ambientales, en la protección y cuidado del mismo. Es por eso que se debe centrar los estudios en el mejoramiento del campo para que esta apoye y surta la ciudad, de igual manera de ser alto potencial para lograr edificar seres sustentables y auto suficientes.

Todos los procesos deben generar mayor conciencia ambiental y así evitar altas cargas de desechos o desperdicios que genera una ciudad desagradable, con un bajo sentido de pertenencia, que no es responsable con el ciudadano; y de un poco modo razonable de vivir en comunidad e involucrarse con altos grados de contaminación que 
perjudica al campo, la hidrografía en general; que obliga a diferenciar momentos de vida de desigualdad, falto de ética moral y con una corta expectativa de recuperación del clima y la destrucción y degradación del mismo, debe existir un mínimo de esperanza y plenitud para que el mundo sea más razonable de las futuras generaciones.

La razonabilidad debe estar encaminado a mejorar estilos de vida, que considere que se debe vivir muy bien, con todas las comodidades que nos blindan las nuevas tecnologías; con ser un objeto de trasformación y recuperación de un planeta que está pidiendo a gritos cambios, que es difícil pero no imposible para lograr cambios significativos y lograr así una directrices para la gestión ambiental urbana, en la construcción constante de medios que facilite la protección y la regulación de sus territorios.

Como punto final de la investigación se deduce que la principal racionalidad de los estudiantes de noveno de la I.E.D Ofelia Uribe de Acosta, es el gran sentido de pertenecía que se demostró en todas las actividades realizadas, logrando así la construcción de futuras herramientas en la implementación de los medios socioambientales para obtener una ciudadanía ambiental, permitiendo un mejor desarrollo del territorio y la territorialidad, obteniendo y mejorando sus niveles de vida; que a su vez creando y formando seres humanos coherentes para afrontar retos ambientales; para lograr el desarrollo y la práctica de estos ejercicios no solo en un grupo de estudiantes, sino en toda nuestra institución y de todas las formas aplicables en otras tanto públicas y privadas del país. 


\section{RECOMENDACIONES.}

La asignatura de Ciencias Sociales, da como una formación social que apunta al desarrollo de competencias, es decir, conjuntos de nociones, estrategias intelectuales, disposiciones y actitudes que permitan a los estudiantes responder ante situaciones de su vida personal y social, en las que se involucra su perspectiva moral, de normas y leyes en una adecuada toma de decisiones, eligiendo entre otras opciones de valor, encarar conflictos y participar en asuntos colectivos, para así juzgar sobre el que cometen un delito ambiental, la debe pagar y con sanciones de retribución al daño ocasiono resarcir la gravedad del daño ambiental en todas sus manifestaciones; y por múltiple razones de incumpla en cualquier sentencia al daño ecológico o medio ambiental; se puede afectar su vida y la honra de los animales y especies naturales, obligando a que cumpla por más de la tercera parte de su sentencia de manera formal y normal en él que debe cumplir en un centro penitenciario.

El desarrollo de competencias demanda su ejercicio práctico, tanto en situaciones de la vida diaria como una persona independiente o un colectivo atenta contra un bien natural de nuestro país; viendo los desempeños del estudiante al concluir el estudio en valores y como las normas y las leyes pueden castigar con penas duras, máximas y reguladas para que se haga justicia. Reflexione sobre la importancia del juicio moral y de leyes como herramientas básicas del quehacer cotidiano en la toma de decisiones, como un centro de conciliación o un juzgado podemos decidir por lo cometió en un acto descalificativo contra la flora o fauna. 


\section{BIBLIOGRAFÍA}

Amartya Sen; premio nobel de Economía, Barcelona, España año 2000. Desarrollo y Libertad.pdf.

Bobadilla, M., Ileana, M., Carbajal, E., Valencia, F. L., \& Borrego, S. Á. (n.d.). Esquema de evaluación para instrumentos de política ambiental.

Bozzano Horacio, (2009) TERRITORIOS: EL MÉTODO TERRITORII.

Bozzano, Horacio (2012). El territorio usado en Milton Santos y la inteligencia territorial en el GDRI INTI: Iniciativas y perspectivas [en línea]. XI INTI International Conference La Plata, 17 al 20 de octubre, La Plata. Argentina. En Memoria Académica. Disponible en:

http://www.memoria.fahce.unlp.edu.ar/trab_eventos/ev.2636/ev.2636.pdf

C, W. R. A. (2014). Luna Azul ISSN 1909-2474 No. 39, julio - diciembre 2014, (39), 250-270.

Capra-fritjof-el-punto-crucial doc, Título del original en inglés The turning point.Publicado por Simon \& Schuster. New York. Copyright fritjof (Capra 1982)

Categoría: Geografía Ciencias Sociales y Humanas Año de Edición: 2003

Ciencias y Ciudadanas. MEN, 2006.

Ciudad, espacio y población: el proceso de urbanización en Colombia. (n.d.).Autor: Varios Autores Editorial: U. Externado de Colombia.

Colmenares Ana Mercedes, Investigación-acción participativa: una metodología integradora del conocimiento y la acción 2012.

Daniel Rico, Los niños del Sumapaz. Héroes clandestinos. (BOGOTA). [Archivo de Video] 2012 https://www.youtube.com/watch?v=nYOVwRjzCol.

Delgadillo Ibeth \& Góngora Fernando, Colecciones Biológicas: Estrategias didácticas Dobson, A. (2010). SDRN Briefing 5: (noviembre)

Documento \# 3, Estándares Básicos de Competencias en lenguaje, matemáticas,

E, A. M. C. (2012). Investigación-acción participativa: una metodología Integradora del conocimiento y la acción, 3(1), 102-115.

El Espectador. "Muiscas buscan preservar sus costumbres frente a la occidentalización”, Bogotá 13 dic 2013 - Tatiana Molina

El Espectador. “Una amenaza en concreto”, Bogotá 26 feb 2011 - Viviana Londoño. 
EL País de España, Torreblanca José Ignacio, sep. 2016

Elliot. Jhon, La investigación-acción en educación 2000.

Eloísa, P., Camargo, M., Facundo, Juan, H., L., Jorge, M.,Segura, D. (2005). Navegaciones.

en la enseñanza-aprendizaje de la Biología, 2009.

Fernando Echarri y Jordi Puig I Baguer, 2008. Educación ambiental y aprendizaje significativo. [Archivo de Video],2012) https://www.youtube.com/watch?v=HYX3dBKfLGY

García Sierra Adriana Alejandra Estratificación, L. A. en Bogotá :2016.

Giner, S., \& Duverger, M. (n.d.). No Title.

Gómez, César; Hadad, M. G. (2005). Territorio e identidad. Reflexiones sobre la construcción de territorialidad en los movimientos sociales latinoamericanos. Trayectorias, 22.

Hacia una nueva definición del concepto "política pública". (2009), (20), 149-187

Hanzelz, CoMpEtEnCiAs CiUdAdAnAs - ExTrAS [Archivo de Video], 2015 https://www.youtube.com/watch?v=FCjErxHEill

http://www.elespectador.com/noticias/judicial/corte-constitucional-prohibe-mineriaparamos-articulo-615389

http://www.resumenlatinoamericano.org/2016/05/04/pensamiento-paulo-freir El-legadodel-pedagogo-brasileno/

https://www.mineducacion.gov.co/1621/article-90891.html

https://www.visitfinland.com/es/ Libro finlandia.pdf.

Internacionales, Análisis Político William Ramírez Tobón director no. 32 SEP/DIC 1997.

Kenneth E. Boulding Las tres caras del poder, Barcelona, Paidós Ibérica, 1993, España

La Educación Ambiental y la Formación de nuevos Ciudadanos y Ciudadanas

Leff, E. (2004). Racionalidad ambiental, La reapropiación social de la naturaleza. Siglo XXI editores, s.a. de c.v. ISBN 968-23-2560-9.

Leff, Enrique, Ecología y capital, racionalidad ambiental, democracia participativa y desarrollo sustentable, Siglo XXI, México 1994 [1986]

Leff, Enrique; Apuesta, L. A., \& La, P. O. R. (2014). La apuesta por la vida. 
Limas Vicente Santiváñez, Aportes de las teorías de Vygotsky, Piaget, Bandura y Bruner, 2005

Lo ambiental y lo social de la aspersión en Colombia ¿Política ambiental o estrategia? (2006), (15), 178-235.

Lorenzo, Z. B. (2008). Educación popular, cultura e identidad desde la perspectiva de Paulo Freire. Obtenido del Consejo Latinoamericano de Ciencias Sociales, Buenos Aires CLACSO:

http://bibliotecavirtual.clacso.org.ar/ar/libros/campus/freire/06Brito.pdf

Los Ocho pasos para el análisis de Políticas Públicas. 2001, Eugene Bardach

Lozano, M. C. (2017). Los procesos de triangulación como estrategia de investigación en las ciencias sociales y humanas. En P. Páramo. (Ed). La recolección de información en las ciencias sociales. Una aproximación integradora (pp.17-35). Bogotá, Colombia: Lee Lemoine Editores.

Marcos, A. (1999). Ética ambiental. Universitas Philosophica, 16(33). 31-57p. Recuperado a partir de http://revistas.javeriana.edu.co/index.php/vniphilosophica/article/view/11396

Mariangeles Payer, Teoría del constructivismo social de Lev Vygotsky en comparación con la Teoría Jean Piaget., 2006

Ministerio del Medio Ambiente y Ministerio de Educación Nacional, (2002). Política Nacional de Educación Ambiental. Recuperado el 26 de noviembre de, http://cmap.upb.edu.co/rid=1195259861703_152904399_919/politica_educacion_ amb.pdf

Molano, F. (2016). El derecho a la ciudad: de Henri Lefebvre a los análisis sobre la ciudad capitalista contemporánea. Folios, (44), 3-19. Monje, C. (2011). Metodología de la investigación cuantitativa y cualitativa. Guía Didáctica. Recuperado el 26 de noviembre de, http://carmonje.wikispaces.com/file/view/Monje+Carlos+Arturo++Gu\%C3\%ADa+did\%C3\%A1ctica+Metodolog\%C3\%ADa+de+la+investigaci\%C3 \%B3n.pdf 
Moran Alonso, N. (2010). Agricultura urbana: un aporte a la rehabilitación integral. Papeles de Relaciones Eco sociales Y Cambio Global, (111), 99-111

Murcia Riaño Diana Milena, La naturaleza con derechos Un recorrido por el derecho internacional de los derechos humanos, del ambiente y del desarrollo, 2012.

ONU, (2015). Resolución aprobada por la Asamblea General el 25 de septiembre de 2015. Transformar nuestro mundo: la Agenda 2030 para el Desarrollo Sostenible. Recuperado el 26 de noviembre de 2017 de http://www.un.org/es/comun/docs/?symbol=A/RES/70/1

Parques nacionalesnc, Parque Nacional Natural Sumapaz [Archivo de Video],2009 https://www.youtube.com/watch?v=93TWa0law3I, 2009)

Parra Torrado Mónica · Trujillo José Daniel, Pobreza, Desigualdad de Oportunidades y Políticas Públicas en América Latina, 2012,

Parte 2 de modulación AM. (n.d.). Retrieved from http://www.profesores.frc.utn.edu.ar/electronica/ElectronicaAplicadalll/Aplicada/C ap03ModulacionAM2.pdf, Parte 4 de 4 peq (2).pdf. (n.d.), Categorización (3 de 4) 1.pdf. (n.d.).

Pertinentes, A. I., Reflexi, L. O. S. C. D. E., \& Educaci, E. N. (n.d.). Investigación y educ ación ambiental.

Revista de Arquitectura. Arquitectura Universidad Católica de Colombia No 7 (2005)

Rodríguez Valbuena, Danilo. (2010). Territorio y territorialidad Nueva categoría de análisis y desarrollo didáctico de la Geografía. Unipluriversidad, 10(3), 12. https://doi.org/1657-4249

ROTH, D., André-Noël (2006) Una política pública ¿Qué es? En: Discurso sin compromiso: La política pública de derechos humanos en Colombia. Ediciones Aurora. Bogotá. Pág. 59-7293

Saber Ambiental: Sustentabilidad, Racionalidad, Complejidad, Poder, Siglo XXI/UNAM/ Pnuma, México, 1998 (tercera edición, revisada y aumentada, 2003; quinta edición, 2007).

Salinas Quintana Pedro, La Vía medioambiental desafíos y proyecciones para un Chile futuro, 2018. 
Santos, B. D. S. (2010). Descolonizar el saber, reinventar el poder. Development and Change (Vol. 44). https://doi.org/10.1111/dech.12026

Tiempo, E. L., \& La, S. D. E. (2008). EL TIEMPO: Secreto de la investigación The Time : The Secret of the Investigation.

Vergara-schmalbach, J. C., Morelos, J., \& Lora, H. (2014). Análisis comparativo de las Políticas Públicas en materia ambiental en países Latinoamericanos A comparative analysis of Environmental Policies management in Latin American countries

Vielma Elma Salas, María Luz, La didáctica, el constructivismo y su aplicación el aula. 2000.

\section{ANEXOS}

\section{ANEXO 1}

Pre análisis de textos del diario El Espectador.

\section{Registro (Entre todos)}

Se dieron las pautas de territorio y territorialidad para desarrollar las actividades.

Alzar la mano para solicitar el turno

Respetar la opinión del otro

Hacer silencio

No burlarme de las equivocaciones del otro

Participar respetuosa y activamente.

\section{Actividad en grupos de 3 a 4 estudiantes.}

Se les pregunta a los estudiantes sobre dos textos específicos que son "Muiscas buscan preservar sus costumbres frente a la occidentalización", de Tatiana Molina, Bogotá 13 de diciembre de 2013 del él diario El Espectador y "Una amenaza concreta", de Viviana Londoño, Bogotá 26 de febrero de 2011 diario El Espectador.

El docente les indica en grupo leer y observar las dos historias del diario El Espectador de Bogotá, y van a descifrar lo que ocurren en su contexto escolar y comunal. Les aclara que van a ir mirando una por una de acuerdo al orden que el docente indique. Observarán leerán con cuidado los dos textos.

Al finalizar cada lectura, el docente interviene con las siguientes preguntas:

-1 ¿Considera que su estilo de vida es muy bueno o aceptable con respecto al video de los niños de Sumapaz?

-2¿Por qué otros niños sufren mucho en su territorio y tienen que hacer grandes esfuerzos para llegar a escuelas retiradas?

-3 ¿Sera que nuestro país tiene una gran biodiversidad, o falta mucho para conseguirla? 
-4 ¿Cómo debemos cuidar nuestro territorio?

$-5 \succsim$ Explique brevemente el primer texto sobre, los muiscas Buscan....?

-6 ¿Por qué nuestros aborígenes consideran sagrados algunos territorios, que en el futuro serán usurpados y pisoteados? Explique su respuesta.

$-7 ¿$ Cómo deben proteger los gobiernos distritales y nacionales estos territorios sagrados?

Para cerrar, se habla del territorio, como parte fundamental del ser humano y en su esencia. Se aclara que lo importante es aprender a manejarlas a partir de ejercicios sencillos.

Finalmente, la actividad se culmina con la siguiente evaluación:

- ¿QUÉ APRENDISTE?

- ¿CÓMO TE HAS SENTIDO?

- ¿QUÉ TE HA GUSTADO?

-¿QUÉ NO TE HA GUSTADO?

ACTIVIDAD DE REFLEXIÓN

\section{ANEXO 2}

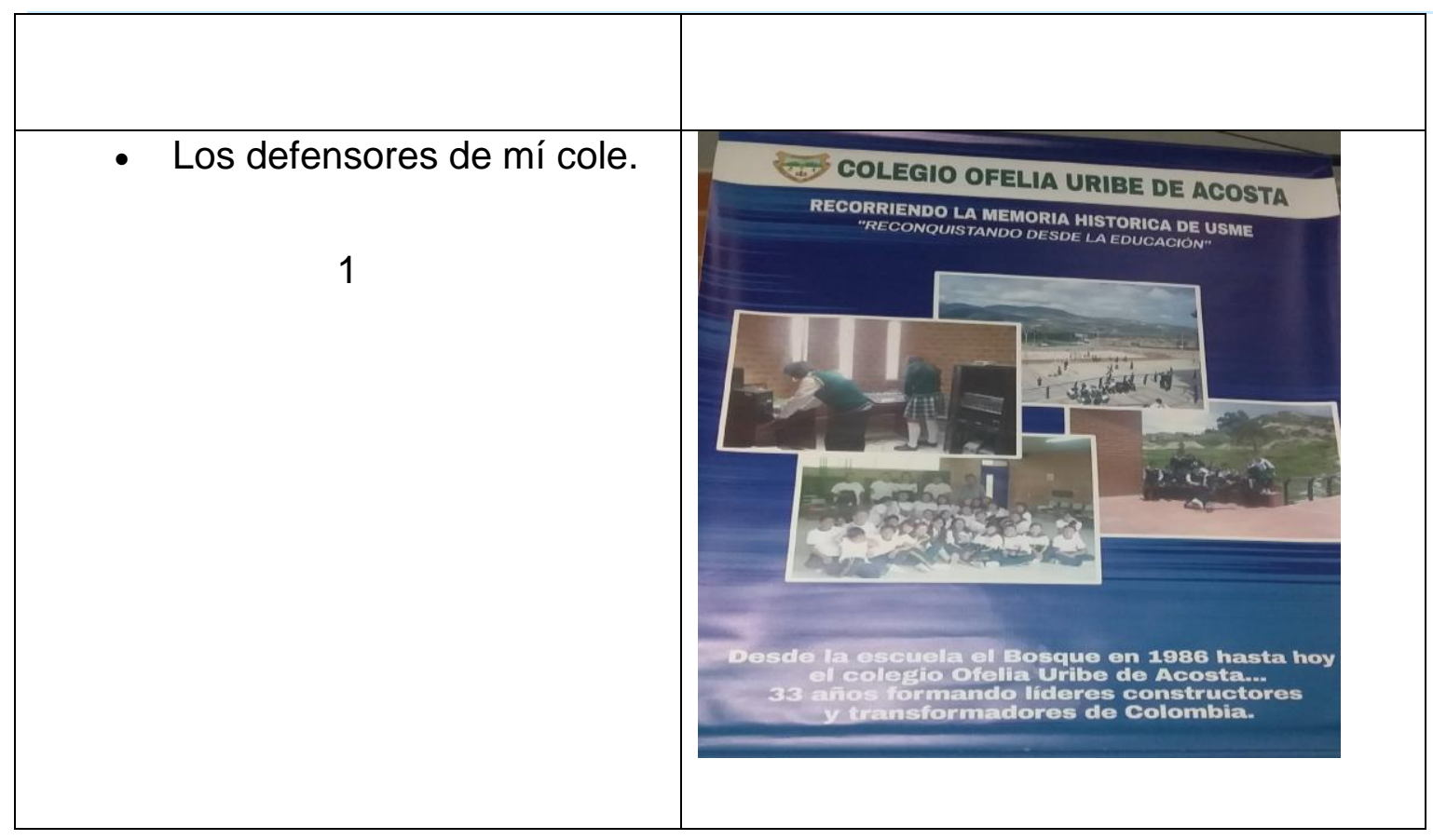



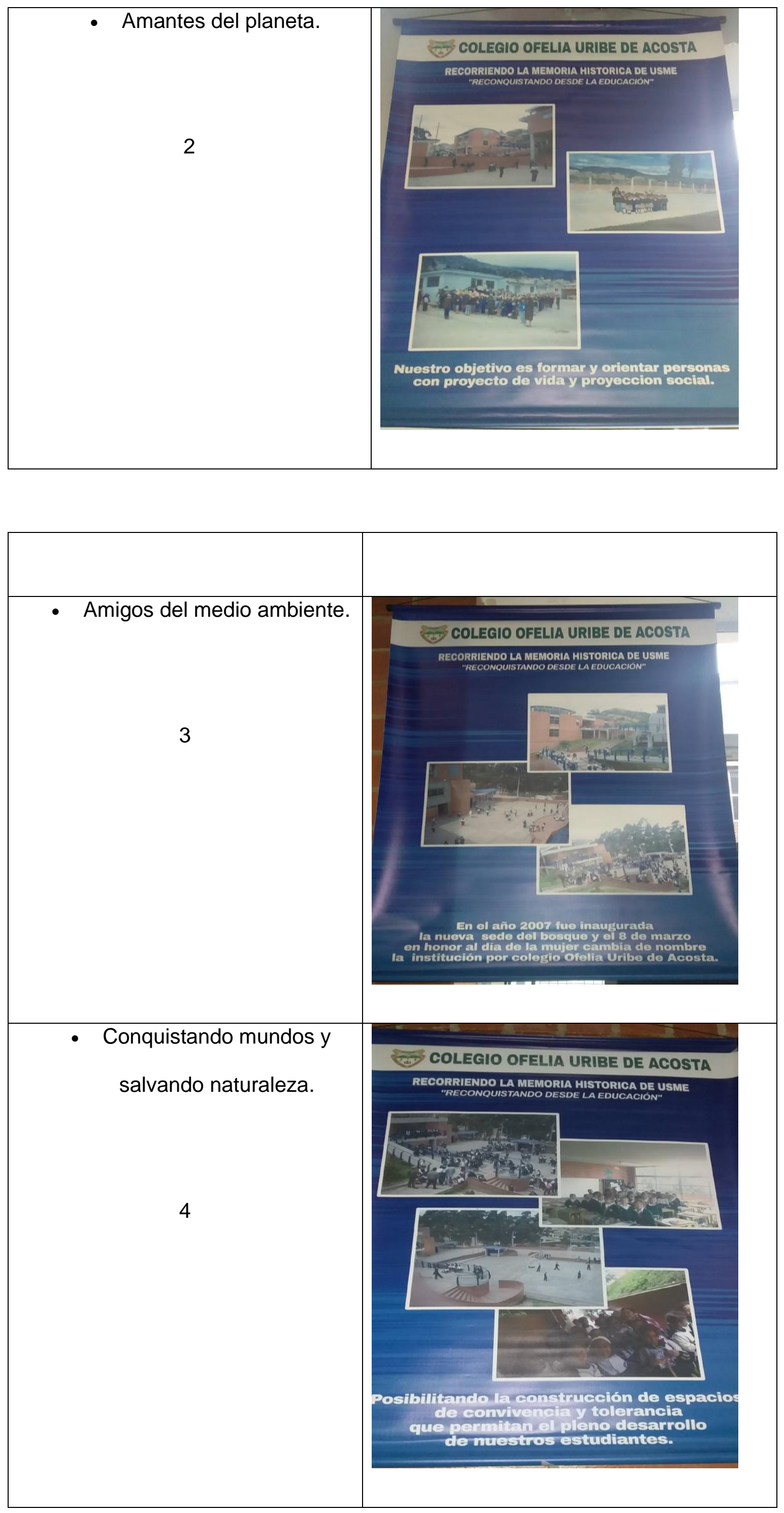


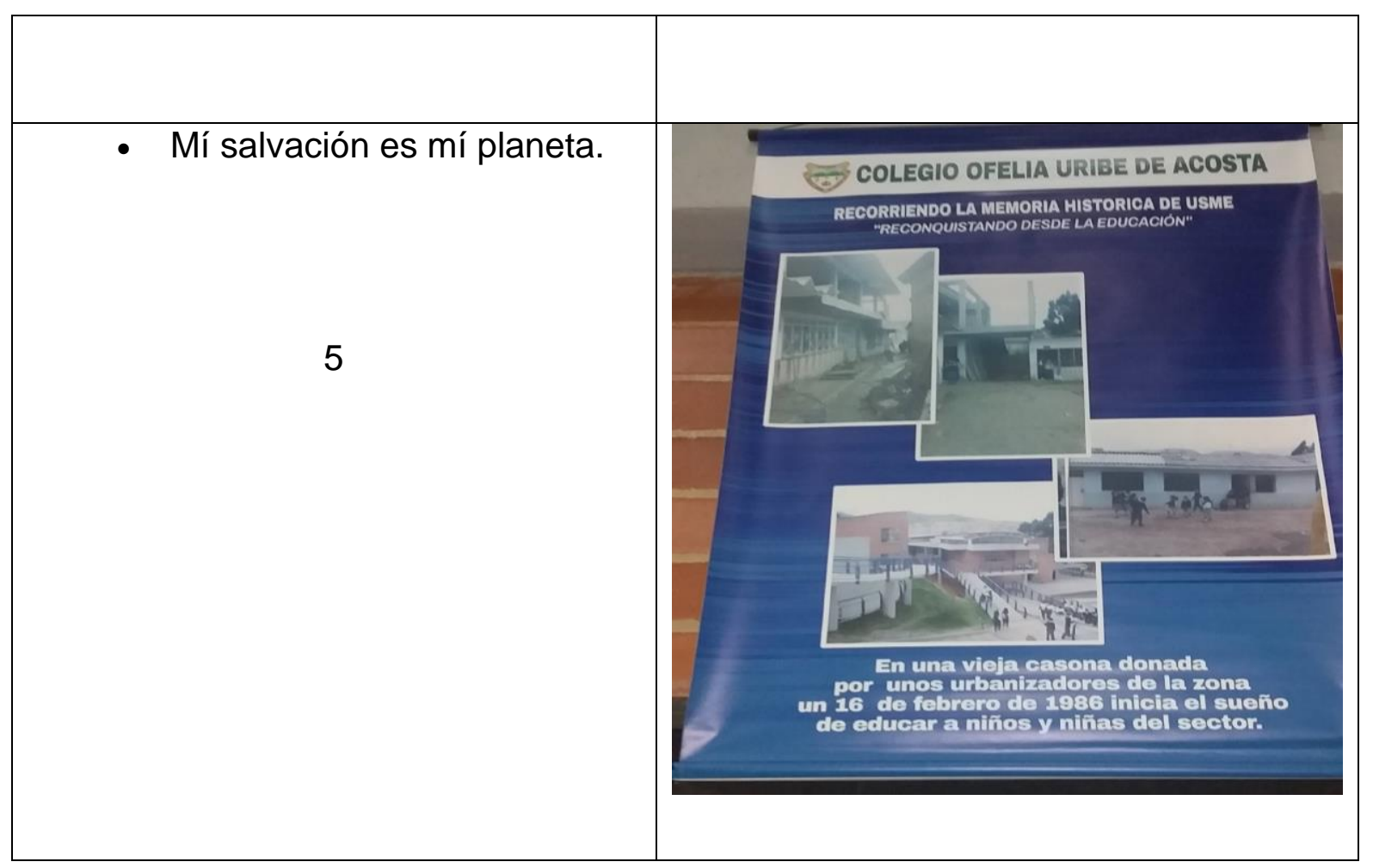

\section{ANEXO 3}

Cuadro comparativo

\begin{tabular}{|c|c|}
\hline SITUACIÓN & COMPARACIÓN \\
\hline $\begin{array}{l}\text { 1. El mundo posible de otros, y } \\
\text { viendo las difíciles condiciones } \\
\text { de acceso a sus colegios, que } \\
\text { madrugan más que resto de la } \\
\text { ciudadanía bogotana, } \\
\text { ejerciendo una admiración y } \\
\text { sentido de pertenecía por sus } \\
\text { raíces, cuidando su territorio. }\end{array}$ & $\begin{array}{l}\text { A través de la ciudadanía ambiental, es } \\
\text { proyectara a los estudiantes de noveno, el } \\
\text { líderes y lideresas medio ambientales, por } \\
\text { medio de la concientización de proyectos } \\
\text { de AULA encaminados a proteger el } \\
\text { territorio sagrado y santuario de la } \\
\text { naturaleza de Usme }\end{array}$ \\
\hline $\begin{array}{l}\text { 2. Generando conciencia activa y } \\
\text { propositiva en la generación } \\
\text { de guías de la naturaleza para } \\
\text { trasferir estas experiencias de } \\
\text { generación tras generación; } \\
\text { motivando sobre todo a la } \\
\text { familia a preservar su } \\
\text { territorio. }\end{array}$ & $\begin{array}{l}\text { Buscando conciencia ambiental por medio } \\
\text { de videos que rescate la biodiversidad de } \\
\text { Colombia y que estamos en un país } \\
\text { privilegiado y que otras potencias quisiera } \\
\text { tener lo que nos pertenece. }\end{array}$ \\
\hline $\begin{array}{l}\text { 3. Genere en mis estudiantes } \\
\text { una exposición que muestran } \\
\text { las iniciativas de construcción } \\
\text { de una ciudadanía ambiental. }\end{array}$ & $\begin{array}{l}\text { Por medio del material reciclaje se elabora } \\
\text { una muestra; para generar conciencia y } \\
\text { del buen uso de material biodegradable, } \\
\text { que puede dar un sentido en los } \\
\text { estudiantes del Ofelia Uribe de Acosta } \\
\text { como parte de la formación medio } \\
\text { ambiental. }\end{array}$ \\
\hline 4. Elaborar algo con papel es & Conocer las rutinas de nuestros \\
\hline
\end{tabular}




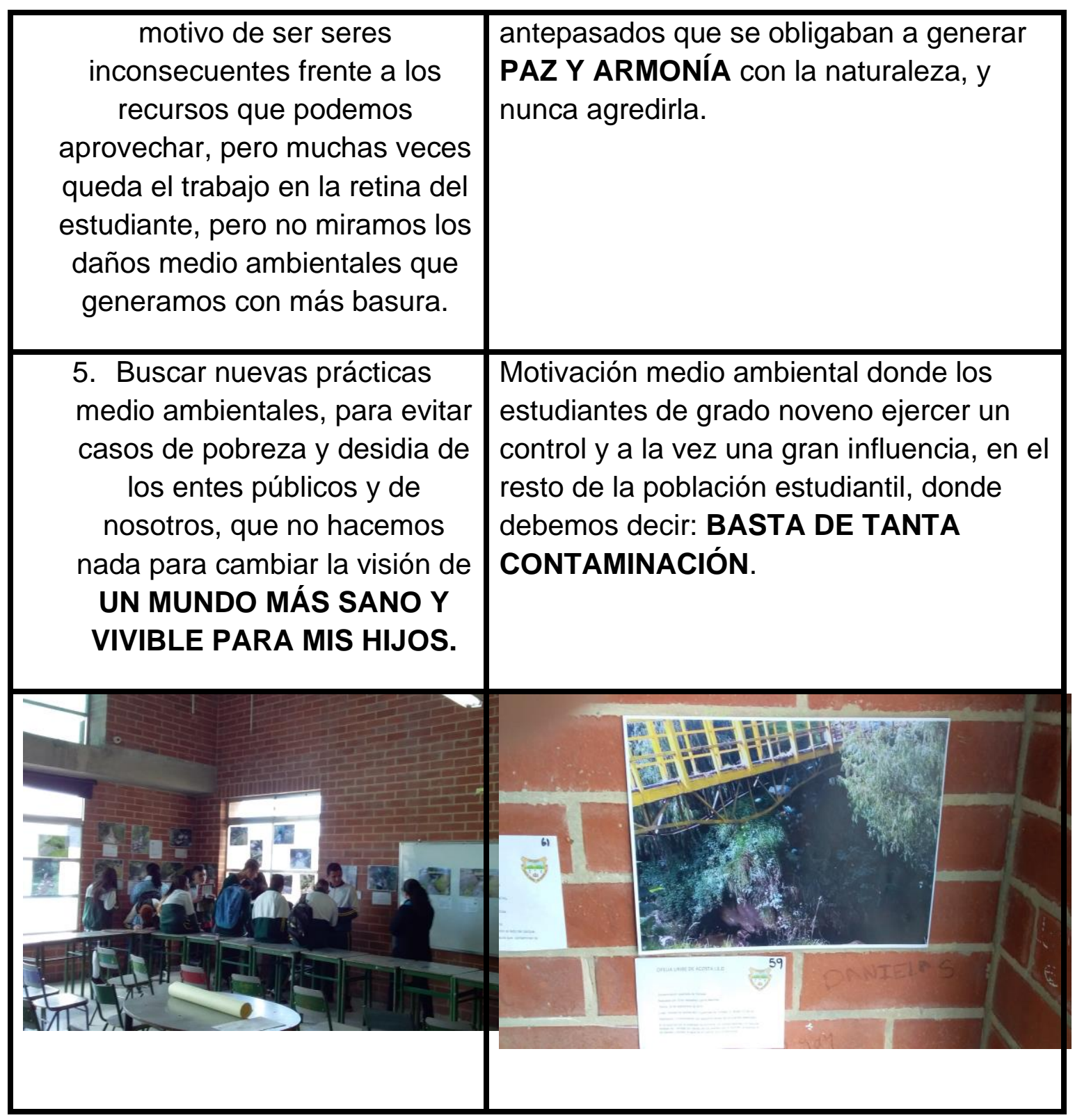

\section{Anexo 4}

El texto de análisis es realizado entre estudiantes y el docente de ciencias sociales:

\begin{tabular}{|c|c|}
\hline $\begin{array}{l}\text { EL ESPECTADOR. } \\
\text { Muiscas buscan preservar sus costumbres } \\
\text { frente a la occidentalización; Bogotá } 13 \text { Dic } \\
2013 \text { - 3:10 PM de Tatiana Molina. }\end{array}$ & $\begin{array}{l}\text { EL ESPECTADOR. } \\
\text { Una amenaza en concreta; Bogotá } \\
26 \text { Feb } 2011 \text { - 10:00 PM } \\
\text { de Viviana Londoño }\end{array}$ \\
\hline $\begin{array}{l}\text { Para comprender este artículo publicado en } \\
\text { diciembre de } 2013 \text {, se argumenta las } \\
\text { necesidades de los estudiantes en su imperiosa } \\
\text { afán de proteger y construir ciudadanía } \\
\text { ambiental a través de medios académicos que } \\
\text { nos ayuda a mejorar y respetar su ambiente, } \\
\text { generando políticas publicas adecuadas a } \\
\text { suministrar medios de protección; construyendo } \\
\text { respeto a lo sagrado, su legado histórico, } \\
\text { mejorando sus vivencias para evitar así } \\
\text { procesos de ocupación y desplazamiento } \\
\text { forzado. Como trabajo trasversal en la } \\
\text { institución Ofelia Uribe de Acosta y principal } \\
\text { gestor de enseñanza ambiental; se espera que }\end{array}$ & $\begin{array}{l}\text { Otro medio de análisis frente a los } \\
\text { abusos de alcaldes y entes } \\
\text { gubernamentales en construir en } \\
\text { zonas de trabajo rural, que ha } \\
\text { significado una herencia generacional } \\
\text { de familias que quien que su huella } \\
\text { ecológica siga por siglos, y que otros } \\
\text { por medio de POT, quieren ser } \\
\text { leguleyos para expropiar y construir } \\
\text { zonas urbanizadas, que donde familias } \\
\text { enteras son reducidas a espacios } \\
\text { inhumanos y sin sentido; debemos } \\
\text { conformar un gran conjunto de redes e } \\
\text { ideas, dando soluciones a estas }\end{array}$ \\
\hline
\end{tabular}




\begin{tabular}{|c|c|}
\hline $\begin{array}{l}\text { los estudiantes de grado noveno identifiquen la } \\
\text { dinámica de un debate y colaboren en de } \\
\text { diseñar de manera grupal acuerdos y pactos de } \\
\text { sano trato e interacción con la naturaleza de su } \\
\text { territorialidad en su localidad; en este caso lo } \\
\text { sagrado se sobrepone a las necesidades de los } \\
\text { urbanistas, alcaldes que quieren convertir } \\
\text { zonas en paisajes resistentes solo al cemento, } \\
\text { y no la campos abiertos para que sea lugares } \\
\text { sostenibles y que de igual manera posibiliten la } \\
\text { construcción de conciencia ambiental, como } \\
\text { principales activistas ambientales que su } \\
\text { DEBER ES PLANTEAR SOLUCIONES POR } \\
\text { MEDIO DE NORMATIVIDAD AMBIENTAL, } \\
\text { QUE A SU VEZ LA FORMA DE ENSEÑAR NO } \\
\text { ES INDEPENDIENTE DE LO QUE SE } \\
\text { ENSEÑA. }\end{array}$ & $\begin{array}{l}\text { localidades que construcción y de } \\
\text { participación, en una gran malla } \\
\text { curricular y de ciudadanía ambiental, } \\
\text { para así construir trabajo social } \\
\text { adecuado para crear una gran } \\
\text { conciencia ambiental, que se logre } \\
\text { unos objetivos claros y PRECISOS EN } \\
\text { LA CONSOLIDACIÓN DE UNA } \\
\text { CULTURA AMBIENTAL Y A SU VEZ } \\
\text { PROTECCIONISTA Y SOSTENIBLE. }\end{array}$ \\
\hline
\end{tabular}

